Poland (mainly) chooses stability and continuity: The October 2011 Polish parliamentary election

Aleks Szczerbiak

A.A.Szczerbiak@sussex.ac.uk

University of Sussex

SEI Working Paper No. 129 
The Sussex European Institute publishes Working Papers (ISSN 1350-4649) to make research results, accounts of work-in-progress and background information available to those concerned with contemporary European issues. The Institute does not express opinions of its own; the views expressed in this publication are the responsibility of the author.

The Sussex European Institute, founded in Autumn 1992, is a research and graduate teaching centre of the University of Sussex, specialising in studies of contemporary Europe, particularly in the social sciences and contemporary history. The SEI has a developing research programme which defines Europe broadly and seeks to draw on the contributions of a range of disciplines to the understanding of contemporary Europe. The SEI draws on the expertise of many faculty members from the University, as well as on those of its own staff and visiting fellows. In addition, the SEI provides one-year MA courses in Contemporary European Studies and European Politics and opportunities for MPhil and DPhil research degrees.

http://www.sussex.ac.uk/sei/

First published in March 2012

by the Sussex European Institute

University of Sussex, Falmer,

Brighton BN1 9RG

Tel: 01273678578

Fax: 01273678571

E-mail: sei@sussex.ac.uk

\section{(C) Sussex European Institute}

\section{Ordering Details}

The price of this Working Paper is $£ 5.00$ plus postage and packing. Orders should be sent to the Sussex European Institute, University of Sussex, Falmer, Brighton BN1 9RG. Cheques should be made payable to the University of Sussex. Please add $£ 1.00$ postage per copy in Europe and $£ 2.00$ per copy elsewhere. See page 35 for a list of other working papers published by Sussex European Institute. Alternatively, SEI Working Papers are available from our website at: http://www.sussex.ac.uk/sei/publications/seiworkingpapers. 


\begin{abstract}
This paper argues that the key to the centrist Civic Platform's victory in the 2011 Polish parliamentary election, the first by an incumbent governing party in post-communist Poland, was its ability to generate fear about the possible consequences of the right-wing Law and Justice party returning to power. Although many of Civic Platform's supporters were disappointed with its slow progress in modernising the country, most voters viewed the party as the better guarantor of stability at a time of crisis and continued to harbour deeply ingrained concerns about the main opposition party. The election appeared to provide further evidence of the consolidation and stabilisation of the Polish party system around the Civic Platform-Law and Justice divide. However, other factors pointed to the dangers of declaring that the Polish party system was 'frozen' around these two political blocs and suggested that it remained vulnerable to further shocks and re-alignments. This was exemplified by the breakthrough of the Palikot Movement in this election which was able to mobilise a constituency that went beyond the existing anti-clerical electorate and represented a genuinely new phenomenon in Polish politics; although it was questionable whether, given its potential structural weaknesses and limitations of its appeal, this new party would be the long-term beneficiary of any revival on the Polish left.
\end{abstract}




\title{
Poland (mainly) chooses stability and continuity: The October 2011 Polish parliamentary election
}

\author{
Aleks Szczerbiak \\ Sussex European Institute, University of Sussex \\ A.A.Szczerbiak@sussex.ac.uk
}

The October 2011 Polish parliamentary election saw a clear victory for the centrist Civic Platform (Platforma Obywatelska: PO) party, which thus became the first incumbent governing party to secure re-election for a second term of office since the collapse of communism in 1989, while the right-wing Law and Justice (Prawo i Sprawiedliwość: PiS) party came a strong but fairly distant second. The agrarian Polish Peasant Party (Polskie Stronnictwo Ludowe: PSL) held on to its share of the vote, giving the governing coalition a small but workable majority in the new parliament. The Palikot Movement (Ruch Palikota: $\mathrm{RP})$, a new anti-clerical liberal party, emerged as the third largest grouping in the new Sejm, the more powerful lower house of parliament, overtaking the once-powerful communist successor party the Democratic Left Alliance (Sojusz Lewicy Demokratycznej: SLD) which suffered its worst ever election defeat.

This paper examines the 2011 Polish parliamentary election and its possible significance for the future development of the Polish party system. It begins by looking at the background and context to the election, surveying the main developments in the Polish party system in the 2007-11 parliament. Section two examines the election campaign before section three moves on to briefly analyse the election results. Finally, section four looks at what, if any, lessons can be drawn from this election about the long-term trajectory of Polish politics, particularly: whether it confirmed the emergence of a stable Polish party system consolidated around a bipolar division between the two big electoral blocs; and what were the future prospects for the Polish left?

The paper argues that the key to the Civic Platform's victory in the 2011 election was its ability to generate fear about the possible consequences of Law and Justice returning to power. Although many of the party's supporters were disappointed with its slow progress in modernising the country, most voters viewed Civic Platform as the better guarantor of stability at a time of crisis and continued to harbour deeply ingrained concerns about Law and Justice. The election appeared to provide further evidence of the consolidation and 
stabilisation of the Polish party system around the Civic Platform-Law and Justice divide. However, other factors pointed to the dangers of declaring that the Polish party system was 'frozen' around these two blocs and suggested that it remained vulnerable to further shocks and re-alignments. This was exemplified by the breakthrough of the Palikot Movement in this election which was able to mobilise a constituency that went beyond the existing anti-clerical electorate and represented a genuinely new phenomenon in Polish politics, although it was questionable whether, given its potential structural weaknesses and limitations of its appeal, this new party would be the long-term beneficiary of any revival on the Polish left.

\section{Polish party development in the 2007-11 parliament}

During the 2007-11 parliament the Polish political scene was very stable with support for the four main parties remaining fairly constant. As Figure 1 shows, the two parties that won the largest share of the vote in the 2007 parliamentary election ${ }^{1}$ remained dominant: Civic Platform, the main governing party led by prime minister Donald Tusk, and Law and Justice, the main opposition grouping led by Jarosław Kaczyński, Mr Tusk's predecessor as prime minister. However, Civic Platform retained a substantial lead and continued to enjoy the steady support of around 40-50\% of the electorate. This was an extraordinarily high level for a governing party and nearly twice that recorded by Law and Justice, its closest rival which remained stuck at around 20-30\%. Civic Platform even managed to emerge un-scathed from a major lobbying and corruption scandal following allegations by the central anti-corruption bureau (Centralne Biuro Antykorupcyjne: CBA) in September 2009 that senior ministers and party leaders had acted covertly on behalf of the gambling industry to block legislation that would have increased betting taxes. Although the 'gambling affair' forced Mr Tusk to dismiss and side-line some of his closest aides, it had no apparent impact on the party's support. $^{2}$

\footnotetext{
${ }^{1}$ For more on the 2007 election, see: R. Markowski, 'The 2007 Polish Parliamentary Election: Some Structuring, Still a Lot of Chaos', West European Politics, Vol 31 No 5, September 2008, pp1055-1068; and A. Szczerbiak, 'The Birth of a Bipolar Party System or Referendum on a Polarising Government: The October 2007 Polish Parliamentary Election', Journal of Communist Studies and Transition Politics, Vol 24 No 3, September 2008, pp415-443.

2 See: N. Maliszewski, 'To już koniec afery hazardowej', 21 February 2010, http://www.polskatimes.pl/ (Accessed 22 February 2010); and P. Śmiłowicz, 'Koniec ery afer’, Newsweek, 14 March 2010.
} 
Figure 1: Patterns of support for the four main Polish parties, 2007-11

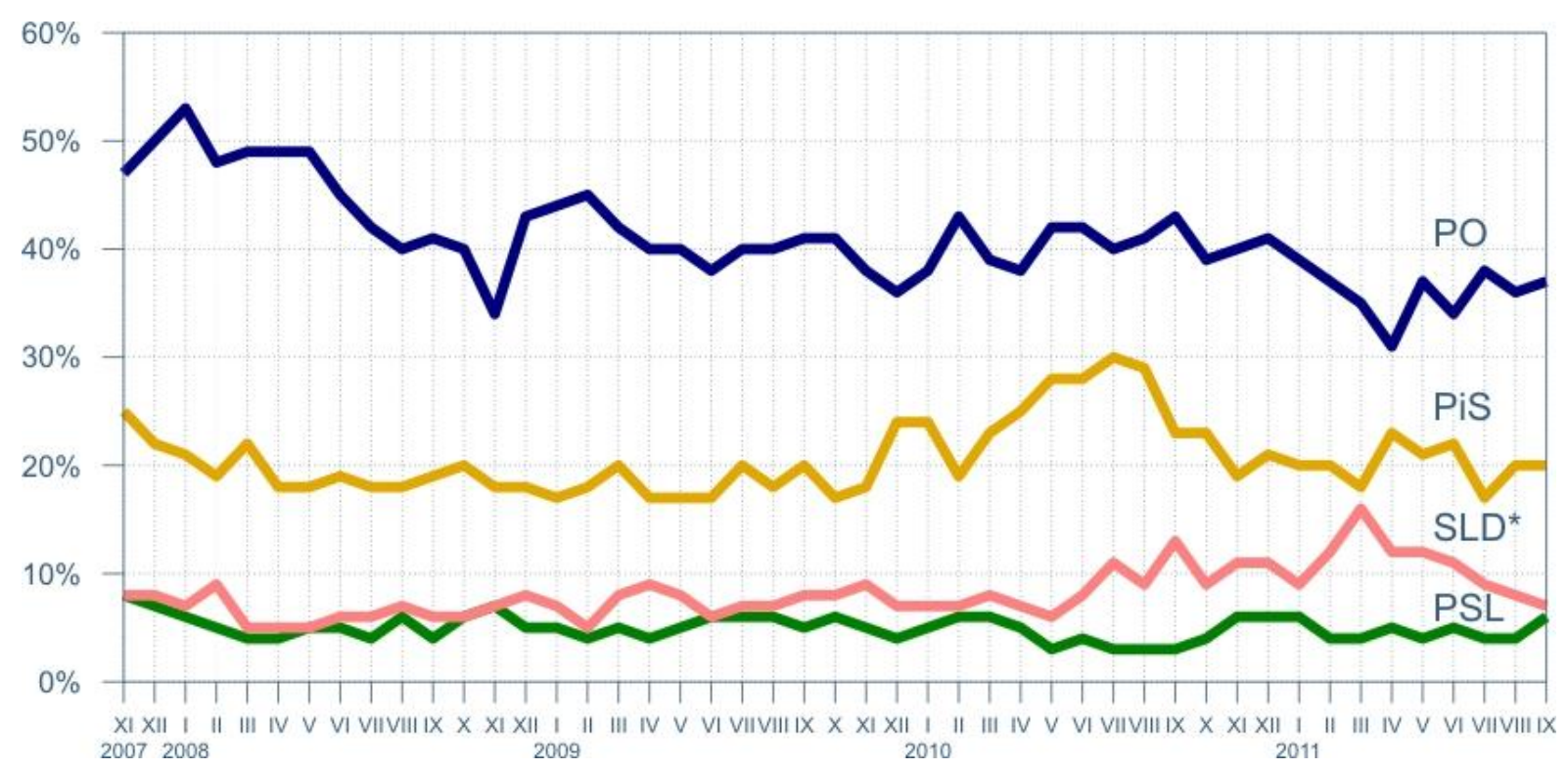

Source: CBOS, Preferencje partyjne we wrześniu, CBOS: Warsaw, September 2011, p2

This was a remarkable and unprecedented record in Polish politics which was more accustomed to the rise and disappearance of governing parties. Although the nature of popular support for the government was often very shallow, Mr Tusk's administration generally had more declared supporters than opponents and throughout the period the prime minister remained one of Poland's most popular politicians. Polish voters clearly warmed to his apparently consensual style compared to that of Mr Kaczyński, his more combative predecessor. For example, a January 2011 CBOS survey found that $40 \%$ of respondents felt that the Tusk government had improved the lives of Polish citizens, compared to only $25 \%$ who felt that about the previous Law and Justice administration. ${ }^{3}$ A June 2011 GfK Polonia survey also found that, although only $22 \%$ felt positively about the Civic Platform-led government and $34 \%$ evaluated it negatively ( $40 \%$ were neutral); this compared with the $74 \%$ who felt negatively about its Law and Justice-led predecessor at the end of its term of office. ${ }^{4}$ Civic Platform and Law and Justice thus had an apparent 'lock' on the Polish electorate and within that duopoly Mr Tusk's party appeared to have an in-built majority.

\footnotetext{
${ }^{3}$ See: CBOS, Reformować czy zarządzać - Polacy o strategii oraz kompetencji rządu i opozycji, March 2011 (January 2011 data), CBOS: Warsaw, pp10-11.

${ }^{4}$ See: E. Olczyk and J. Stróżyk, 'Premier słabnie, ale wciąż mocny’, Rzeczpospolita, 18-19 June 2011.
} 
As Figure 1 shows, opinion polls also showed the Democratic Left Alliance, the smaller leftwing opposition grouping, third with around 10-15\% support. The Alliance had previously been one of the strongest parties in Poland and governed from 1993-97 and 2001-5 but was in the doldrums since its support collapsed in the 2005 parliamentary election following its involvement in a series of spectacular high level corruption scandals. ${ }^{5}$ National polls often showed the Peasant Party, Civic Platform's junior coalition partner in government, struggling to secure the $5 \%$ vote share required to obtain parliamentary representation. However, the party more than held its own in the October-November 2010 regional assembly elections when it came third with over $16 \%$ of the vote nationally. ${ }^{6}$

The Civic Platform-Peasant Party coalition was much more cohesive than most of its predecessors; indeed, this was probably one of the most stable governments in post-1989 Poland. The key to its stability was the political partnership between Mr Tusk and Peasant Party leader Waldemar Pawlak, who held the office of deputy prime minister and economy minister. The two leaders were generally able to defuse tensions and problematic issues before they became too contentious or escalated into major public disputes. This was helped by the fact that the Peasant Party was primarily an office-seeking party with a clearly defined rural-agricultural electoral constituency, making it a pragmatic negotiating partner with a fairly narrow policy agenda. For example, a May 2011 CBOS survey found that by far the most important reason cited by Peasant Party voters for supporting the party (by $46 \%$ of respondents) was the fact that it represented and defended the interests of people like themselves; other parties' voters rarely if ever cited this as a reason. ${ }^{7}$ Importantly, the fact that the two parties had somewhat different core electorates and bases of support, with the Civic Platform primarily an urban party and the Peasant Party's voters drawn mainly from rural communities, meant that they were not in direct competition for the same voters. The Peasant Party also appeared to have drawn lessons from earlier periods as a member of coalition governments during the 1990s and early 2000s when it was a very difficult partner and distanced itself publicly from the main ruling party whenever its poll ratings declined or the government encountered difficulties. However, this time around Mr Pawlak's party

\footnotetext{
5 See: A. Szczerbiak, "Social Poland" Defeats "Liberal Poland": The September-October 2005 Polish Parliamentary and Presidential Elections', Journal of Communist Studies and Transition Politics, Vol 23 No 2 , June 2007, pp203-232 .

${ }^{6}$ See: J. Stróżyk, 'Platforma wygrała, ale to PSL świętuje', Rzeczpospolita, 25 November 2010.

${ }^{7}$ See: CBOS. Oczekiwania i motywacje wyborcza Polaków, July 2011 (May 2011 data), CBOS: Warsaw, p3.
} 
pursued a very different strategy: making a virtue of its predictability and self-consciously trying to project an image as a constructive and moderating force in Polish politics. ${ }^{8}$ At the same time, it concentrated on 'delivering' for its core rural-agricultural electorate both in terms of policy - by, for example, protecting the heavily state-subsidised farmers social security system - and through its control of government-appointed posts and agencies, especially in the agricultural sector. ${ }^{9}$ As long as Civic Platform was careful not to push ahead too quickly with policy reforms that threatened to undermine the interests of the Peasant Party's core farming constituency, or on other issues where it felt that it might not have been able to count on its partner's support, then the coalition functioned smoothly.

Nonetheless, Civic Platform's support was shallow and not based on any particular enthusiasm for the government or its policies. For sure, Mr Tusk's administration was generally felt to have done a competent job and took credit for ensuring that Poland was the only EU member that came through the first wave of the global financial crisis in 2008-9 without falling into recession. However, although Civic Platform had made a bold campaign pledge in the 2007 election that it would deliver an 'economic miracle', fearing the political consequences Mr Tusk's government failed to capitalise on its electoral mandate and move ahead quickly with the more radical social and economic policy reforms that were advocated by many analysts as necessary for the party to live up to its promises. As a consequence, the government was heavily criticised, even by its own supporters, for its lack of major achievements and ambition. ${ }^{10}$ This led to a steady erosion in the government's public approval ratings and satisfaction with its performance. For example, a January 2011 CBOS survey found that $72 \%$ of respondents felt that the government had failed to implement its election promises, 69\% did not trust government information on important political and economic matters, 66\% felt that it avoided difficult decisions and $60 \%$ that it avoided tackling the most important issues facing the country. ${ }^{11}$ Similarly, a June 2011 CBOS survey found that while most Poles considered Mr Tusk to be likeable (65\%), intelligent (62\%),

\footnotetext{
${ }^{8}$ See: M. Strąk, 'Długi marsz PSL', 20 June 2008, www.gazeta.pl (Accessed 23 June 2008).

${ }^{9}$ See: K. Naszkowska, 'Psy szczekają, karawana PSL idzie dalej’, 7 May 2008, www.gazeta.pl (Accessed 8 May 2008).

${ }^{10}$ See, for example: J. Paradowska, 'Antysalonowiec', Polityka, 9 October 2010; W. Gadomski, 'Fani odeszli od Tuska', 15 February, www.wyborcza.pl (Accessed 18 February 2011); M. Szułdrzyński, 'Gdy piar przestaje działać...', Rzeczpospolita, 16 February 2011; M. Janicki and W. Władyka, 'Bunt elit', Polityka, 19 February 2011; R. Kalukin, 'Cholernie ciężko popreć Platformę', 22 Feburary 2011, www.wyborcza.pl (Accessed 24 February 2011); Ł. Warzecha, 'Platforma odczarowana', Rzeczpospolita, 24 February 2011; and R. Krasowski, 'Premier, który sie boi', Rzeczpospolita, 30 March 2011. Cf: J. Kucharcyzk, 'Liberalizm w wersji pragmatycznej', Rzeczpospolita, 1 April 2011.

${ }^{11}$ See: Reformować czy zarzadzać, pp6, 8 and 9.
} 
dynamic (61\%), hard-working (47\%) and competent (45\%), they also felt that he had not fulfilled their expectations. This could be seen clearly in the fall, compared with his first year in office, in the number who felt that the prime minister was decisive (from 57\% to $37 \%$ ), confronted difficult issues (from 50\% to 33\%), was consistent and determined (from $48 \%$ to $28 \%$ ), and delivered on his promises (from $35 \%$ to $17 \%$ ). ${ }^{12}$

In its defence, the government's supporters argued that, initially at least, it was hugely constrained by the fact that it had to 'co-habit' with President Lech Kaczyński, the Law and Justice party leader's twin brother. Given his very close links with Law and Justice, $\mathrm{Mr}$ Kaczyński quickly emerged as a natural focus for opposition and found himself in a perpetual and debilitating conflict with the government. ${ }^{13}$ Although he had few executive prerogatives, Mr Kaczyński could veto legislation and on a number of occasions refused to sign key elements of the government's programme. ${ }^{14}$ The government lacked the three-fifths parliamentary majority in the Sejm required to over-turn the presidential veto and therefore needed the support of the Democratic Left Alliance in key votes to secure it. This became more difficult when, at the party's June 2008 congress, Grzegorz Napieralski defeated the incumbent Wojciech Olejniczak in a close and divisive leadership contest. While $\mathrm{Mr}$ Olejniczak, along with most of the party's best known leaders, had favoured co-operating with the government against Law and Justice, Mr Napieralski adopted a new political strategy based on making fewer concessions to, and distancing his party from, the Tusk administration. ${ }^{15}$

However, in April 2010 President Kaczyński and 95 others, including many senior Polish officials and public figures, died in a plane crash at Smolensk in western Russia on their way to a memorial service honouring the thousands of Polish officers killed by the Soviet NKVD secret police in the Katyn forest in 1940. Mr Kaczyński's untimely death and the subsequent election of Bronisław Komorowski, a Civic Platform nominee, as President in July $2010^{16}$ removed an important constitutional obstacle to the implementation of the government's

\footnotetext{
${ }^{12}$ See: CBOS, Portret Donalda Tuska po ponad trzech latach sprwowania urzędu premiera, July 2011 (June 2011 data), CBOS: Warsaw, pp2, 5.

${ }^{13}$ See: K. Kik, 'PiS - partia destrukcyjnego czynu', Rzeczpospolita, 28 July 2008.

${ }^{14}$ See: M. Janicki and W. Władyka, 'Mniejszościowy rząd większości', Polityka, 17 May 2008.

${ }^{15}$ See: C. Łazarewicz, 'Zapateralski', Polityka, 31 May 2008.

${ }^{16}$ For more on the 2010 election, see: Aleks Szczerbiak, 'Europe and the June/July 2010 Polish Presidential Election', European Parties Elections and Referendums Network Election Briefing No 55, August 2010, http://www.sussex.ac.uk/sei/documents/epern-election-briefing-no-55.pdf; and J. Rosset, 'The 2010 presidential election in Poland', Electoral Studies, Vol 30 No 1, January 2011, pp223-244.
} 
programme and left Mr Tusk's party controlling all the main organs of state power. Nonetheless, with a parliamentary election scheduled for autumn 2011, the government still remained instinctively cautious of introducing radical reforms that might alienate voters. The Peasant Party's presence as a junior coalition partner also acted as a block on the introduction of certain reforms. However, Civic Platform's reluctance to accelerate reforms was also part of its broader governing philosophy which tried to turn programmatic timidity and ideological eclecticism into a virtue. ${ }^{17}$ Civic Platform's approach of 'reform by small steps' was integral to the its long-term strategy of transforming itself from an economically liberal and socially conservative centre-right party into a non-ideological and all-inclusive centrist grouping that was attractive to a very wide spectrum of voters; what some critics dubbed a 'post-political' party of power. ${ }^{18}$

In fact, rather than any particular enthusiasm for Mr Tusk's government or its programme, Civic Platform's greatest electoral asset was the public's continued aversion to the turbulent and often emotionally charged style of politics that most Poles associated with the 2005-7 Law and Justice-led governments and Jarosław Kaczyński in particular. ${ }^{19}$ For example, a February 2009 PBS DGA survey found that $36 \%$ of Civic Platform voters admitted that one of the main reasons why they supported their party was fear of Law and Justice returning to power. ${ }^{20}$ Similarly, a June-July 2011 CBOS survey found that by far the largest number of respondents $(47 \%)$ said that they would definitely not vote for Law and Justice compared with only $21 \%$ who said that they would never support Civic Platform. ${ }^{21}$ Even the government's supporters often defended the Tusk administration on the grounds that its main

\footnotetext{
${ }^{17}$ See, for example: J. Cieński, 'Rząd realistycznych małych kroków', Rzeczpospolita, 22 December 2008 ; J. Makowski, 'Polska modernizowana piórem', Rzeczpospolita, 20 December 2010; and D. Tusk, 'Premier Tusk: 'Czego dokonaliśmy, co nam się nie udało', 12 March 2011, www.wyborcza.pl (Accessed 15 March 2011).

${ }^{18}$ For a range of critical and sympathetic analyses, see: B. Wildstein, 'Bezideowość polityki polskiej', Rzeczpospolita, 27-28 February 2010; P. Skwieciński, 'Platforma w poszukiwaniu utraconego sensu', Rzeczpospolita, 8 March 2011; R. Grochal, 'Platforma środka', 14 June 2011, www.wyborcza.pl (Accessed 16 June 2011); M. Janicki and W. Władyka, 'Tuskism', Polityka, 21-28 June 2011; J. Makowski, 'Można wybrać tylko wino i przystawkę', Rzeczpospolita, 9 September 2011; P. Zaremba, 'Platforma à la Kołakowski', Rzeczpospolita, 17-18 September 2011; and J. A. Majcherek, 'Liberał po przejściach', Polityka, 21-27 September 2011.

${ }^{19}$ See, for example: R. A. Ziemkiewicz, 'Pułapka Kaczyńskiego', Rzeczpospolita, 15 March 2010; B. Wildstein, 'Nie będzie końca politycznej wojny', Rzeczpospolita, 5 July 2010; Ł. Warzecha, 'Kaczyński w teatrze Tuska', Rzeczpospolita, 22 October 2010; and I. Janke, 'Efektowna kurtka premiera', Rzeczpospolita, 18 July 2011.

${ }^{20}$ See: W. Szcacki, 'Sondaż “Gazety”: Wciąż wielka nieufność do PiS', 12 February 2009, www.wyborcza.pl (Accessed 17 February 2009).

${ }^{21}$ See: CBOS, Wybory parlamentarne 2011 - zainteresowanie, pewność głosowania, alternatywy wyborcze, elektoraty negatywne, July 2011 (June-July 2011 data), CBOS: Warsaw, p10.
} 
achievement was to restore social harmony and, for all his alleged indecisiveness, Polish voters seemed to prefer Mr Tusk's apparently more consensual style of politics. ${ }^{22}$

This was encapsulated in the notion of rejecting the so-called 'Fourth Republic', a programme based on a radical critique of post-1989 Poland as corrupt and requiring far-reaching moral and political reform. Originally an idea that enjoyed quite broad political support (including figures linked to Civic Platform), the 'Fourth Republic' came to be used increasingly by $\mathrm{Mr}$ Tusk's party as a pejorative term to characterise the programme and practices of the Law and Justice-led governments and tool for mobilising the majority of Polish voters who rejected Mr Kaczyński's party as too confrontational. ${ }^{23}$ This strategy proved a great success in the 2007 election, which Mr Tusk's party turned it into a referendum on the 'Fourth Republic'. ${ }^{24}$ The basis of Civic Platform's continuing high levels of popular support and key to its continued electoral success was, therefore, its ability to frame political debate in terms of a choice between support for and opposition to the 'Fourth Republic', and to position itself as, whatever its other shortcomings, the party best placed to prevent Law and Justice returning to power.

Law and Justice found it increasingly (and frustratingly) difficult to break this logic. ${ }^{25}$ The party did make various attempts to present a more conciliatory image and focus on 'bread and butter' economic issues and modernising Poland, pushing its traditional themes (such as fighting crime and corruption, and making a more fundamental break with the communist past) into the background. ${ }^{26}$ But most of the time these efforts had little impact on the party's fortunes. The only period when Law and Justice appeared to be narrowing Civic Platform's opinion poll lead was in the run up to the June-July 2010 presidential election that followed the Smolensk tragedy. Running an extremely effective and sure-footed campaign directed by politicians from the party's moderate wing, Mr Kaczyński used the snap election as an opportunity to re-invent his party by softening its rhetoric and reaching out to centrist

\footnotetext{
${ }^{22}$ See, for example: J. Kucharczyk, 'PiS nie doścignie Platformy', Rzeczpospolita, 12 January 2010.

${ }^{23}$ See: P. Śpiewak, 'Pięć lat po czwartej', Polityka, 26 June 2010; and R. Bugaj, 'Osierocona idea IV RP', Rzeczpospolita, 6 July 2010.

${ }^{24}$ See: 'The Birth of a Bipolar Party System or Referendum on a Polarising Government?'

${ }^{25}$ See, for example: M. Karnowski, 'PiS jak ze snów Platformy,' 28 July 2008, www.dziennik.pl (Accessed 30 July 2008).

${ }^{26}$ See, for example: K. Manys, 'PiS chce radykalnie zmienić oblicze', Rzeczpospolita, 5 January 2009; M. Janicki, 'Prezes jak nowy', Polityka, 7 February 2009; and W. Wybranowski, 'PiS porzuca "układu", Rzeczpospolita, 17 February 2010.
} 
voters. $^{27}$ In the event, by winning $36.5 \%$ in the first round (compared to $41.5 \%$ for $\mathrm{Mr}$ Komorowski) Mr Kaczyński managed to force a second round run-off, which he lost but with a respectable $47 \%$ of the votes.

However, almost as soon as the election results were announced Mr Kaczyński quickly abandoned the more moderate and consensual tone that he adopted during the presidential campaign and returned to his earlier confrontational style. ${ }^{28}$ Dis-associating himself from the moderates who had run his presidential campaign, the Law and Justice leader launched a series of bitter attacks on the ruling party and refused to co-operate with the newly elected President, describing his election as a 'misunderstanding' and symbolically boycotting his inauguration. Mr Kaczyński started to make the Smolensk air crash and subsequent investigation into its causes a central issue for the party, saying that the government bore 'moral and political responsibility' for the errors that led to the tragedy through its relentless attacks on his brother and lack of care for his security. He also accused the prime minister of weakness and naively playing into Russia's hands by allowing Moscow to oversee the main crash investigation. $^{29}$

Mr Kaczyński's inflammatory rhetoric and focus on the Smolensk tragedy squandered the political capital that the party had accumulated during the presidential election. His uncompromising stance may have buttressed support for Law and Justice among its core supporters. However, as the party's disappointing showing in the autumn 2010 local elections showed (when it failed to win control of any of Poland's 16 regional authorities), over-doing the aggressive language and using Smolensk as a political weapon prevented Law and Justice from offering a coherent alternative to Civic Platform and eroded support for the party among more moderate voters. Indeed, Mr Kaczyński's post-election volte face forced a group of key Law and Justice moderates led by his presidential campaign manager Joanna KluzikRostkowska to break away from the party and, in November 2010, form a new centre-right

\footnotetext{
${ }^{27}$ See, for example: $Ł$. Warzecha, 'Komorowski w pułapce Kaczyńskiego', Rzeczpospolita, 17 June 2010; and I. Krzemiński, 'Polityka resentymentu', Rzeczpospolita, 2 August 2010.

${ }^{28}$ See, for example: P. Śpiewak, 'Powrót talibanu', Polityka, 24 July 2010; P. Gursztyn, 'Więcej chaosu niż perfidii', Rzeczpospolita, 28 July 2010; A. Nowakowska and D. Wielowiejska, 'PiS oblężoną twierdzą', 10 September 2010, www.wyborcza.pl (Accessed 13 September 2010); M. Janicki, 'Świat według prezesa', Polityka, 18 September 2010; and A. Stankiewicz and P. Śmiłowicz, 'Samotność mściciela', Newsweek, 19 September 2010.

${ }^{29}$ See, for example: I. Janke, 'Ostatnia wojna prezesa Kaczyńskiego', Rzeczpospolita, 13 September 2010; and J. Stróżyk and W. Wybranowski, 'Kaczyński: Polska się budzi', Rzeczpospolita, 11 April 2011.
} 
grouping called 'Poland is the Most Important' (Polska Jest Najważniejsza: PJN), which had been Mr Kaczyński’s presidential campaign slogan. ${ }^{30}$

\section{The Campaign}

At the start of the campaign, the only questions thus appeared to be about the extent of Civic Platform's victory, whether or not its junior coalition partner would be able to cross the 5\% threshold, and if Mr Tusk's party would need to find new or additional coalition partners to govern? Civic Platform's position was strengthened further when Mr Kaczyński's party's campaign got off to a false start following comments made at a June Brussels seminar, organised by Law and Justice MEPs, by Father Tadeusz Rydzyk, director of the controversial Radio Maryja broadcaster, who accused the Tusk government of using 'totalitarian' methods against his media organisation. The clergyman was an important Law and Justice supporter and his media conglomerate extremely influential among Catholic-nationalist voters who comprised a key element of the party's core electorate among older, church-going voters. ${ }^{31}$ However, Father Rydzyk also alienated many of the centrist voters whom Law and Justice was trying to attract and his remarks were widely condemned, even by some commentators who were generally sympathetic to Mr Kaczyński's party. ${ }^{32}$ Civic Platform, on the other hand, began the election by holding a successful national convention at which party members, led by Mr Tusk, debated the party's activities since its formation in 2001 and drew up a balance sheet of its four years in government. The ruling party's campaign was based on setting out a general vision for the evolutionary reform and modernisation of Poland aimed at making the country a strong player within Europe. Mr Tusk's party tried to take credit for Poland's relatively strong economic performance, arguing that it was in large part due to various government measures that the country remained a 'green island of growth' within Europe. At a time of increasing economic uncertainty, they argued, Poles should choose a safe and competent team that had at least started the process of modernisation and investment

\footnotetext{
${ }^{30}$ See: P. Gursztyn and W. Wybranowski, 'Z PiS do stowarzyszenia', Rzeczpospolita, 17 November 2010; and R. Grochal and W. Szacki, 'Ruch Kluzik-Rostkowskiej', 17 November 2010, www.wyborcza.pl (Accessed 17 November 2010).

${ }^{31}$ For example, a November 2011 CBOS survey found that $70 \%$ of regular Radio Maryja listeners voted for Law and Justice compared to only 14\% who supported Civic Platform. See: CBOS, Dwadzieścia lat Radia Maryja, CBOS: Warsaw, December 2011 (September-November 2011 data), p9.

${ }^{32}$ See, for example: P. Zaremba, 'To gorzej niż zbrodnia, to błąd', Rzeczpospolita, 27 June 2011.
} 
in the country's future prosperity and development; exemplified by the party's cautious initial campaign slogan 'Poland Under Construction'. 33

Civic Platform also used its tenth-anniversary convention to highlight that it was winning over new converts from rival parties, as well-known figures from across the political spectrum declared their intention to run on the party's candidate lists. ${ }^{34}$ Thus, one of the convention highlights was a speech by Mrs Kluzik-Rostkowska, perhaps the most controversial of the 'switchers', where she declared that she would be leaving 'Poland is the Most Important' to support Civic Platform. ${ }^{35}$ At the other end of the political spectrum, the convention also the saw the accession to the party of well-known centre-left politicians, following the earlier defection to Civic Platform of Bartosz Arłukowicz, one of the most high profile and popular left-wing figures linked to the Democratic Left Alliance. Mr Arłukowicz who, ironically, first gained national prominence due to his high profile role in a special parliamentary commission set up to investigate the 'gambling affair' - joined the government as the prime minister's plenipotentiary for contact with the 'socially excluded'; a ministerial position created especially for him. These defections were part of a concerted long-term strategy designed to broaden Civic Platform's appeal and weaken its political opponents by co-opting some of their best known politicians and authority figures. ${ }^{36}$ In his keynote convention address, Mr Tusk stressed that he saw the presence of such a wide range of views and opposing opinions within Civic Platform as one of the party's strengths. ${ }^{37}$

Much of the summer campaigning was dominated by the so-called 'debate about debates' which started when Mr Tusk challenged Mr Kaczyński and senior Law and Justice politicians to take part in a series of televised confrontations with Civic Platform's incumbent ministers. ${ }^{38}$ Mr Tusk wanted to highlight Law and Justice's lack of experienced, high quality specialists who could handle the top jobs of running the country, given that Mr Kaczyński’s

\footnotetext{
${ }^{33}$ See: K. Manys, 'Platforma rusza z kampanią', Rzeczpospolita, 6-7 August 2011; and M. Szułdrzyński, 'Tusk na budowie', Rzeczposolita, 18 August 2011. For more on Civic Platform's election programme and appeal, see: M. Janicki, 'Czy Tusk zasługuje na więcej', Polityka, 14-20 September 2011; A. Nowakowska and D. Wielowiejska, 'Program wyborczy PO. Mały realizm zderza się z kryzysem', 22 September 2011, www.wyborcza.pl (Accessed 23 September 2011); and R. Grochal, 'Państwo PO', 1 October 2011, www.wyborcza.pl (Accessed 5 October 2011).

${ }^{34}$ See: E. Olczyk and A. Górski, 'Donald Tusk do PO: idźcie i zwyciężajcie', Rzeczpospolita, 13 June 2011.

${ }^{35}$ See: P. Gursztyn, 'Kluzik-Rostkowska wzmocni Platformę', Rzeczpospolita, 13 June 2011.

${ }^{36}$ See: P. Gursztyn, 'Partia Tuska skręca w lewo', Rzeczpospolita, 19 May 2011.

${ }^{37}$ See: PO, 'Donald Tusk: Służymy Polsce i Polakom', 11 June 2011, www.platforma.org (Accessed 21 June 2011)

${ }^{38}$ See: P. Wroński, 'Tusk: zapraszam na debatę', 22 August 2011, www.wyborcza.pl (Accessed 28 August 2011).
} 
party lost many of its most talented and experienced members in the Smolensk crash. ${ }^{39}$ The Civic Platform leader also tried to capitalise on the fact that he was a much more accomplished TV debater than Mr Kaczyński. Mr Tusk out-performed the Law and Justice leader in their last debate before the 2007 election, which was widely considered to be a turning point in that campaign, and this made Mr Kaczyński extremely wary of participating in such forums alongside the Civic Platform leader. ${ }^{40}$ Mr Kaczyński therefore insisted on a series of terms and conditions that he knew the Civic Platform leader would never accept (stipulating that the debates be held in the Law and Justice party headquarters) or were unmeasurable (announcing that he would only debate when the prime minister agreed to 'lower the white flag', implying that he had been insufficiently robust in both confronting vested interests at home and defending Poland abroad).

Initially, it seemed that Law and Justice's refusal to debate with Civic Platform would lose the party support by making it appear weak and unprofessional. ${ }^{41}$ However, this was not the case and, as the campaign progressed, it became an increasingly tight race. ${ }^{42}$ Mr Kaczyński's strategy of embarking on a nationwide speaking tour instead of participating in televised debates appeared to work, while Civic Platform, having originally expected to cruise to victory, found itself increasingly on the defensive and struggling to develop a clear campaign message. Moreover, although Mr Kaczyński’s campaign speeches could be quite sharp in tone, once again Law and Justice tried to moderate its more abrasive rhetoric. Knowing it had little scope to win over many voters beyond its core, the party concentrated instead on running a 'softer and gentler' campaign aimed at de-mobilising those Civic Platform voters who were motivated primarily by fear of Mr Kaczyński. ${ }^{43}$ Mr Kaczyński also avoided focusing too much on the Smolensk tragedy which party strategists knew was not a major concern to voters beyond its core electorate and gave the impression that the party was backward looking and obsessed with a single issue. ${ }^{44}$ At the same time, they knew that the party could rely upon the 'below the radar' support of the many civil society initiatives that

\footnotetext{
${ }^{39}$ See: P. Śmiłowicz, 'Czy to koniec PiS?’ Newsweek, 18 April 2010.

${ }^{40}$ See: R. Grochal, 'Dlaczego PiS unika debat', 25 August 2011, www.wyborcza.pl (Accessed 28 August 2011).

${ }^{41}$ See: P. Wroński, 'Weekend: runda dla Tuska', 22 August 2011, www.wyborcza.pl (Accessed 28 August 2011).

${ }^{42}$ See, for example: W. Szacki, 'Sondaż “Gazety”. Kampania służy PiS', 21 September 2011, www.wyborcza.pl (Accessed 21 September 2011); and M. Czech, 'Wiatr wieje dla Kaczyńskiego', 27 September 2011, www.wyborcza.pl (Accessed 27 September 2011).

${ }^{43}$ See, for example: A. Nowakowska, 'Kaczyński nuci kołysankę wyborcy PO', 28 September 2011, www.wyborcza.pl (Accessed 30 September 2011); M. Janicki and W. Wladyka, 'Rozwibrowanie', Polityka, 28 September-4 October 2011; and I. Janke, 'Platforma przestała być trendy', Rzeczpospolita, 3 October 2011.

${ }^{44}$ See: J. Stróżyk and W. Wybranowski, 'O czym nie mówią politycy’, Rzeczpospolita, 6 October 2011.
} 
arose among those who were still fired up by the relentless search for the culprits behind the Smolensk tragedy. ${ }^{45}$ Although it was not part of the official campaign, the Smolensk issue thus consolidated and mobilised the party's most committed supporters, which it knew could be very significant in the event of a low turnout.

In its official campaign, however, Law and Justice attempted to construct a broader appeal by concentrating on issues such as unemployment, health care, opportunities for young people, and the poor state of Poland's infrastructure. Mr Kaczyński's party seized on the fact that many Poles felt that, even taking the economic crisis into account, Mr Tusk's government had not delivered the increase in opportunities that it had promised in 2007, a message exemplified by its main campaign slogan 'Poland Deserves More'. ${ }^{46}$ Indeed, one of the leitmotifs of the Law and Justice campaign became a question posed by pepper farmer Stanisław Kowalczyk who spoiled what was meant to be a routine campaign visit for $\mathrm{Mr}$ Tusk. In front of live TV cameras, Mr Kowalczyk complained about how he and other farmers had not received any help from the government after heavy gales had devastated farms in his region and asked in an emotional voice: 'How do I live now Mr prime minister, how do I live?' The line was quickly picked up by Mr Kaczyński's party and Mr Kowalczyk was invited to speak at a Law and Justice election convention. ${ }^{47}$ Interestingly, Law and Justice also made a particularly strong pitch to younger voters, who were crucial in getting Civic Platform elected in 2007. Law and Justice correctly identified a 'glass ceiling' that many young Poles, especially those from smaller towns and rural areas, felt that they encountered and the fact that, in spite of economic growth, Poland still had high levels of youth unemployment and even many of those who managed to get a job struggled to obtain (much less pay) mortgages and support their families. This included a high profile campaign poster featuring a number of its younger female candidates with the strap-line: 'Come with us!' which contrasted strongly with the (generally middle aged and greying) men who featured in many of the Civic Platform campaign adverts. ${ }^{48}$

\footnotetext{
${ }^{45}$ See, for example: I. Janke, 'Naród Kaczyńskiego', Rzeczpospolita, 20 May 2011; J. Paradowska, 'Wszyscy ludzie prezesa', Polityka, 1-7 June 2011; and 'Kaczyński nuci kołysankę wyborcy PO'.

${ }^{46}$ See, for example: W. Wybranowski, 'PiS atakuje rząd Tuska spotami', Rzeczpospolita, 11 July 2011 ; D. Kołakowska, 'Prezes rozsuwa drzwi', Rzeczpospolita, 19 July 2011; W. Wybranowski, 'PiS chce uderzyć gospdarką', Rzeczpospolita, 25 August 2011; W. Wybranowski, 'PiS w wersji light', Rzeczpospolita, 9 September 2011; and M. Szułdrzyński, 'Spójny przekaz, miły lider', Rzeczpospolita, 10 October 2011.

${ }^{47}$ See: I. Ryciak, 'Ostry paprykarz', Newsweek, 26 September-2 October 2011.

${ }^{48}$ See, for example: I.T. Miecik and I. Ryciak, 'Generacja PiS', Newsweek, 19-25 September 2011.
} 
For its part, Civic Platform knew that it could not concentrate solely on its relatively modest achievements in office. Although it came up with a rather defensive slogan for the final stage of the campaign ('We will do more'), ${ }^{49}$ the party also developed a strong counter-offensive. Firstly, it drew upon Mr Tusk, perhaps the party's single greatest electoral asset and certainly its most effective campaigner, who undertook a nationwide tour on the so-called 'Tuskobus'. The road show of semi-planned encounters, speeches, interviews and press conferences ensured continual media coverage as the Civic Platform leader visited poorer towns and was seen to listen to ordinary voters' concerns and complaints. Mr Tusk also showed that we was not afraid to face down angry anti-government football supporters who regularly attacked him for what they claimed was his administration's excessively authoritarian crackdown on hooliganism. ${ }^{50}$

Secondly, in the final stages of the campaign Civic Platform significantly ratcheted up its anti-Law and Justice rhetoric. For example, it released an extremely powerful campaign advert showing scuffles between a group who protested against the removal of a cross that was erected in front of the presidential palace after the Smolensk tragedy and the authorities, together with violent scenes involving football hooligans. The so-called 'defenders of the cross' were associated with the Mr Kaczyński's party and some Law and Justice leaders had also expressed sympathy for known football hooligans defending them as 'patriots'. The advert ended with the phrase, 'They are going to vote, what about you?' implying that a Law and Justice victory would hand Poland over to the kind of people depicted in the film. ${ }^{51}$ Civic Platform's efforts to mobilise its more passive supporters were also helped by a controversial book-length interview with Mr Kaczyński published towards the end of the campaign. Here the Law and Justice leader said that German Chancellor Angela Merkel's ascent to power did not happen 'by chance alone' and suggested that she was trying to re-build German imperial power. Law and Justice was thus forced to spend much of the last week of the campaign trying to explain what exactly Mr Kaczyński meant to say and responding to claims that the party was playing on anti-German sentiments. ${ }^{52}$

\footnotetext{
${ }^{49}$ See: P. Semka, 'Platformersi są zmęczeni', Rzeczpospolita, 12 September 2011.

${ }^{50}$ See, for example: R. Grochal, 'Czy Tusk sobie poradzi z pytaniem Jak zyć?' 23 September 2011, www.wyborcza.pl (Accessed 23 September 2011); and J. Stróżyk, 'Kibice spotkali się z Donaldem Tuskem', Rzeczpospolita, 27 September 2011.

${ }^{51}$ See: J. Stróżyk and W. Wybranowski, 'Finisz z inżynierią strachu', Rzeczpospolita, 4 October 2011.

${ }^{52}$ See: W. Szacki, 'Puder opada z twarzy Kaczyńskiego', 5 October 2011, www.wyborcza.pl (Accessed 5 October 2011); 'Angela Merkel w polskiej kampanii', Rzeczpospolita, 6 October 2011; and A. Stankiewiz, P. Śmiłowicz and J. Tańska, 'Finisz był ostry’, Newsweek, 10-16 October 2011.
} 
$\underline{\text { Results }}$

As Table 1 shows, the election saw a clear victory for Civic Platform, which thus became the first incumbent governing party to secure re-election for a second term of office since the fall of communism in 1989. Although most commentators expected the party to win, it did so by a larger than expected margin garnering $39.18 \%$ of the vote while Law and Justice came a strong but fairly distant second with 29.89\%. As a result, Mr Tusk's party won 207 seats in the 460-member Sejm, compared with 157 for Law and Justice.

Table 1: October 2011 Polish parliamentary election results to the Sejm

\begin{tabular}{|l|c|c|c|c|c|}
\hline & \multicolumn{2}{|c|}{$\mathbf{2 0 0 7}$} & \multicolumn{2}{c|}{$\mathbf{2 0 1 1}$} & \multirow{2}{*}{$\begin{array}{c}\text { \% } \\
\text { Change }\end{array}$} \\
\hline Civic Platform (PO) & \% & Seats & \% & Seats & -2.33 \\
\hline Law and Justice (PiS) & 41.51 & 209 & 39.18 & 207 & -2.22 \\
\hline Palikot Movement (RP) & 32.11 & 166 & 29.89 & 157 & +10.02 \\
\hline Polish Peasant Party (PSL) & & & 10.02 & 40 & -0.55 \\
\hline Democratic Left Alliance (SLD)* & 8.91 & 31 & 8.36 & 28 & -4.91 \\
\hline Polish is the Most Important (PJN) & 13.15 & 53 & 8.24 & 27 & +2.19 \\
\hline New Right (NP) & & & 2.19 & & +1.06 \\
\hline Polish Labour Party (PPP) & 1.00 & & 0.55 & & -0.45 \\
\hline
\end{tabular}

Source: Polish State Electoral Commission (http://www.pkw.gov.p1/)

* In 2007, the party contested the election as part of the 'Left and Democrats' (LiD) coalition with Polish Social Democracy (SdPl) and the Democrats (Demokraci).

Civic Platform's victory was due, in part, to its ability to craft an extremely broad appeal and identify itself skilfully with mainstream public opinion. However, given that the size of the two main parties 'core' electorates was roughly similar, ${ }^{53}$ one of the main factors determining the election outcome was always likely to be the level of turnout. Many observers felt that a lower turnout would benefit Law and Justice whose core supporters were more highly motivated and easier to mobilise than Civic Platform's less disciplined voters. For example, a June-July 2011 CBOS survey found that $69 \%$ of Law and Justice voters said that they were certain to vote for that party (increasing to $76 \%$ when including those who were almost certain) compared to only $56 \%$ of Civic Platform voters. ${ }^{54}$ The same survey found that $42 \%$

\footnotetext{
${ }^{53}$ A September 2011 TNS OBOP survey put this at $18 \%$ for Civic Platform and 17\% for Law and Justice. See: W. Szacki, 'PiS blisko Platformy', 16 September 2011, www.wyborcza.pl (Accessed 19 September 2011). See also: M. Szreder, 'Lider słabszy, niż pokazują sondaże', Rzeczpospolita, 21 July 2011.

${ }^{54}$ See: Wybory parlamentarne 2011, p5.
} 
of Law and Justice voters would not consider voting for any other party compared to only $31 \%$ of Civic Platform voters who said the same. ${ }^{55}$ The latter had turned out in large numbers in 2007 mainly because they disliked Mr Kaczyński's confrontational style of politics, so the key to the party's victory would be its ability to generate fear about the possible consequences of Law and Justice returning to power. ${ }^{56}$

Table 2: Turnout in post-1989 Polish elections (\%)

\begin{tabular}{|c|c|c|}
\hline & Presidential & Parliamentary \\
\hline 1990 & $60.63(1)$ & \\
\hline 1991 & $53.40(2)$ & 43.20 \\
\hline 1993 & & 52.13 \\
\hline 1995 & $64.70(1)$ & \\
\hline 1997 & $68.23(2)$ & 47.93 \\
\hline 2000 & 61.12 & 46.29 \\
\hline 2001 & & 40.57 \\
\hline 2005 & $49.74(1)$ & 53.88 \\
\hline 2007 & $50.99(2)$ & \\
\hline 2010 & & 48.92 \\
\hline 2011 & $54.94(1)$ & \\
\hline
\end{tabular}

Source: '15 chętnych na jeden mandate,' Rzeczpospolita, 8-9 October 2011; and Polish State Electoral Commission (http://www.pkw.gov.pl/)

The election result suggested that, although many of the party's supporters were disappointed with its slow progress in modernising the country, most voters still viewed Civic Platform as the better guarantor of stability at a time of crisis. ${ }^{57}$ For example, a May 2011 CBOS survey found that the most important reason given by Civic Platform voters for supporting the party (by $19 \%$ of respondents) was that there was a lack of alternatives and it represented the 'lesser evil' ${ }^{58}$ Moreover, Mr Kaczyński's mistakes during the final stages of the campaign, such as his comments about Mrs Merkel, provided Mr Tusk's party with the ammunition that it needed for an effective counter-mobilisation of its more passive supporters. In the event, as Table 2 shows, at $48.92 \%$ the level of turnout in 2011 was around the norm for much of the

\footnotetext{
${ }^{55}$ See: Ibid, p8.

${ }^{56}$ See: R. Grochal, 'Jak Platforma chce sprowokować PiS', 27 August 2011, www.wyborcza.pl (Accessed 28 August 2011); and M. Majewski and P. Reszka, 'Platforma czeka na wielkie "bum!'”, Rzeczpospolita, 8 September 2011.

${ }^{57}$ See: P. Skwieciński, ‘Antykaczyzm skuteczny’, Rzeczpospolita, 1 September 2011.

${ }^{58}$ See: Oczekiwania i motywacje wyborcza Polaków, p3.
} 
1990s and early 2000s (although down from 53.88\% in 2007) which meant that enough Civic Platform supporters came out to vote to give Mr Tusk's party its historic second victory by a very clear margin.

As Table 1 also shows, the Peasant Party won $8.36 \%$ of the vote, finishing fourth among the five parties that crossed the 5\% threshold, and 28 seats in the new Sejm. This gave the governing coalition 235 seats in total, enough to secure a small but workable parliamentary majority. Although some party leaders had hoped for more, ${ }^{59}$ this was a relatively good result for the agrarian party given that many opinion polls during the campaign (and, indeed, previous parliament) showed its support hovering around the 5\% mark, and it was the first time that the party had managed to broadly hold on to its share of the vote after a period in office. In fact, as Table 3 shows, the Peasant Party had the most developed grassroots organisation of any Polish party with an estimated 70-128,000 members. It also had the highest level of local territorial penetration with, for example, 4,175 councillors in the smallest rural parishes (those with fewer than 20,000 voters) compared with 1,655 for Law and Justice, 981 for Civic Platform and 596 for the Democratic Left Alliance. ${ }^{60}$ Consequently, much of the party's campaigning took place at the local level and was often not picked up by the national media; ${ }^{61}$ as a result of which opinion polls often tended to under-state the party's actual level of support.

Table 3: Membership of the five main Polish parties, 2010-11

\begin{tabular}{|l|c|}
\hline Party & Number of members \\
\hline Polish Peasant Party & $70,000-128,000$ \\
\hline Democratic Left Alliance & 58,500 \\
\hline Civic Platform & $45,000-50,000$ \\
\hline Palikot Movement & 40,000 \\
\hline Law and Justice & $18,000-22,000$ \\
\hline
\end{tabular}

Source: L. Antkiewicz, 'Polacy nie garną się do partii. Zyskuje tylko PO', 8 February 2010, www.gazeta.pl (Accessed 9 February 2010); R. Grochal, 'Platforma pęcznieje', 24 February 2020, www.wyborcza.pl (Accessed 25 February 2010); and A. Kublik, 'SLD się liczy', 5 November 2011, www.wyborcza.pl (Accessed 10 November 2011).

\footnotetext{
${ }^{59}$ See: K. Naszkowska, 'Wygrany-przegrany PSL', 13 October 2011, www.wyborcza.pl (Accessed 14 October 2011).

${ }^{60}$ See: 'Platforma wygrała, ale to PSL świętuje'.

${ }^{61}$ See: E. Olczyk and K. Manys, 'Chłop potęga i basta', Rzeczpospolita, 4-5 June 2011; and I. Janke, 'Zywią i bronią swoich', Rzeczpospolita, 10 October 2011.
} 
Apart from the re-election of Mr Tusk's government, the other major story of this election was the success of the Palikot Movement, an anti-clerical liberal party formed less than a year before by the controversial and flamboyant businessman and former Civic Platform deputy Janusz Palikot. As Table 1 shows, the Palikot Movement ended up winning just over $10 \%$ of the vote, which translated into 40 seats making it the third largest grouping in the new Sejm, overtaking the longer-established Peasant Party and the once-powerful Democratic Left Alliance. With his radical and outspoken attacks on the Law and Justice party, Mr Palikot had previously been a useful outrider for Civic Platform. However, after the Smolensk tragedy he started to become a liability when he blamed the crash on the irresponsibility of the Kaczyński brothers and claimed that the late President may have been under the influence of alcohol during the ill-fated flight (earlier he had accused Mr Kaczyński of being an alcoholic). At the end of 2010, Mr Palikot left Civic Platform complaining at what he saw as its conservative tilt and formed his own political grouping with a socially liberal programme that included reducing the influence of Poland's influential Catholic Church in public life, the de-criminalisation of so-called 'soft' drugs, abortion on demand, and more rights for sexual and other minorities including the legalisation of same-sex civil unions.

Until the final stages of the election, support for the Palikot Movement stood at a mere 1-3\%. However, Mr Palikot ran a dynamic and extremely well executed campaign trying to move beyond his frivolous image and present himself as a serious political leader and intellectual. For example, a November 2011 CBOS report showed how the number of voters who said that they trusted Mr Palikot increased from 24\% in August 2011 to 36\% in October, while the number who distrusted him fell from $46 \%$ to $36 \%$ over the same period (although by November the numbers had returned to their pre-election levels). ${ }^{62}$ Knowing that the impact of his original anti-clerical appeal was likely to be limited, Mr Palikot began to place greater emphasis upon a broader message of business-friendly, small-state social liberalism, promising to bring about a 'modern, secular, socially oriented, civic and friendly' state. The Palikot Movement thereby attracted a significant number of younger voters who wanted efficient government but also had socially liberal views on lifestyle issues and felt that Civic Platform and the Democratic Left Alliance were too establishment-oriented and deferential towards the Catholic Church. ${ }^{63}$ For example, the 2011 Polish Election Survey found support

\footnotetext{
${ }^{62}$ See: CBOS, Wyborcy Ruchu Palikota, November 2011 (September-October 2011 data), CBOS: Warsaw, pp23.

${ }^{63}$ See: P. Zaremba, 'Ze wsparciem establishmentu', Rzeczpopospolita, 10 October 2011.
} 
for the Palikot Movement stood at: 21\% among 18-24 year-olds, 24\% among young first-time voters and $27 \%$ among students. It also found that $20 \%$ of those who never attended church services had voted for Mr Palikot as had $17 \%$ of those who only went a few times a year, compared to $0 \%$ among those went several times a week and $5 \%$ who attended weekly. ${ }^{64}$ $18 \%$ of voters who supported Civic Platform in 2007 and turned out to vote again in 2011 (34\% of them abstained this time) switched their votes to the Palikot Movement. ${ }^{65}$ In total, $43 \%$ of all Palikot Movement voters had previously voted for Civic Platform. ${ }^{66}$

The success of Mr Palikot's 'new left' was also achieved at the expense of the Democratic Left Alliance, previously the dominant party on the Polish centre-left which suffered its worst ever election defeat finishing, as Table 1 shows, a distant fifth with only 8.24\% of the vote and 27 seats. The result was a huge disappointment for the party and prompted $\mathrm{Mr}$ Napieralski to stand down as leader. Only a year earlier, he ran a surprisingly vigorous presidential election campaign to finish an impressive third with a much better than expected $13.7 \%$ of the vote. ${ }^{67}$ This appeared to establish the Democratic Left Alliance as the dominant force on the Polish left and Mr Napieralski as the party's un-questioned leader. However, it proved to be a false dawn and the party lost ground as it struggled to find an effective response to the series of high profile defections to Civic Platform by prominent left-wing politicians such as Mr Arłukowicz. ${ }^{68}$

Mr Napieralski became too self-confident after his surprisingly good presidential election result and, as a consequence, when drawing up the party's election candidate lists paid more attention to internal party manoeuvring than choosing candidates who could attract broad support. ${ }^{69}$ For example, he reneged on earlier promises to give prominent positions to wellknown figures such as gay rights activist Robert Biedroń and pro-abortion campaigner Wanda Nowicka, thereby prompting their defection to the Palikot Movement and damaging

\footnotetext{
${ }^{64}$ See: Wyborcy Ruchu Palikota, p4; and CBOS, Wierność wyborcza - przeplywy między elektoratami partyjnymi z roku 2007 i 2011, November 2011 (October-November 2011 data), CBOS: Warsaw, p7.

${ }^{65}$ See: Wyborcy Ruchu Palikota, p4.

${ }^{66}$ See: Wierność wyborcza, p6. See also: M. Cześnik, 'Ruch Palikota urósł na Platformie', 11 October 2011, www.wyborcza.pl (Accessed 12 October 2011).

${ }^{67}$ See: I. Janke, 'Napieralski chwilowo ratowany', Rzeczpospolita, 21 June 2010.

${ }^{68}$ See: E. Olczyk, ‘SLD - pięć porażek i dwa sukcesy’, Rzeczpospolita, 9-10 July 2011; and R. Ziemkiewicz, 'Zakładnicy nostalgii za PRL', Rzeczpospolita, 10 October 2011.

${ }^{69}$ See: E. Olczyk, 'Sojusz traci wiarygodność', Rzeczpospolita, 12 August 2011; and P. Gursztyn, 'Ludzie lidera SLD wyparli innych' Rzeczpospolita, 26 September 2011.
} 
the party's standing among potential supporters on the liberal left. ${ }^{70}$ At the same time, the Democratic Left Alliance campaign lacked the Palikot Movement's energy and vigour and failed to develop a distinctive and coherent message. ${ }^{71}$ For example, while Mr Napieralski originally argued that the party needed to position itself as a clearer left-wing alternative to the Civic Platform-led government during the campaign he signed a co-operation agreement with the Business Centre Club employers' organisation. Similarly, having begun his leadership by positioning himself as the 'Polish Zapataro', a reference to the Spanish Socialist prime minister who had introduced a radical transformative programme of social liberalism and anti-clericalism, during the election campaign, like many previous Democratic Left Alliance leaders, Mr Napieralski ultimately proved extremely cautious about giving too high a profile to religious issues and embracing cultural liberalism too wholeheartedly. Consequently, the party was completely un-prepared for the emergence of a major challenger on its liberal left flank, in the shape of the Palikot Movement that took a much clearer-cut position on, and appeared to show much greater determination in tackling. moral-cultural issues. $^{72}$

\section{The long-term trajectory of Polish politics}

In terms of the long-term trajectory of Polish politics, this election once again confirmed that the so-called 'post-communist divide' between the ex-communist and post-Solidarity electoral blocs that had dominated and appeared to provide a structural order to the Polish party system during the $1990 \mathrm{~s}^{73}$ had definitely passed into history. However, as far as future scenarios were concerned, two main sets of question emerged. Firstly, did the election confirm the emergence of a stable Polish party system consolidated around a bi-polar division between Civic Platform and Law and Justice? Secondly, turning to possible sources of realignment within the Polish party system, what were the future prospects for the Polish left and, specifically, what did the emergence of the Palikot movement mean for its future development?

\footnotetext{
${ }^{70}$ See: C. Michalski, 'Duże ambicje, mało charyzmy’, Newsweek, 21 August 2011.

${ }^{71}$ See, for example: R. Walenciak, 'Grzechy Grzecha', Polityka, 14-20 September 2011; and A. Nowakowska and D. Wielowiejska, 'Przegrana lewicy garniturowej', 12 October 2011, www.wyborcza.pl (Accessed 13 October 2011).

72 See: A. Leszczyński, 'Smutna przyszłość dla lewicy', 11 October 2011, www.wyborcza.pl (Accessed 13 October 2011).

${ }^{73}$ See: M. Grabowska. Podzial postkomunistyczny: Spoleczne podstawy polityki w Polsce po 1989 roku, Warsaw: Wydawnictwo Naukowe Scholar, 2004.
} 
It is easy to forget that the Civic Platform-Law and Justice duopoly emerged conjecturally indeed, almost accidentally - in 2005 and that originally the socio-demographic profiles of the two party electorates (and, arguably, many of their policies) were actually very similar. ${ }^{74}$ Indeed, at the time they were seen as natural coalition partners. However, the fact that this divide not only endured but strengthened and went on to dominate and structure the Polish political scene for the next six years suggested that it was more authentic than might have originally appeared. ${ }^{75}$ Indeed, as the divisions between the two party elites widened and deepened so did those between their electorates, exemplified by the decline in Civic Platform and Law and Justice voters who put the other party as their second voting preference from $45 \%$ and $37 \%$ respectively in July 2005 to only $3 \%$ and $6 \%$ in June-July $2011 .^{76}$ The same June-July 2011 CBOS survey found that $75 \%$ of Civic Platform voters said that they would definitely not vote for Mr Kaczyński's party and 68\% of Law and Justice voters said the same about Mr Tusk's (even more than the $48 \%$ who said that they would not vote for the Democratic Left Alliance). ${ }^{77}$ Moreover, while it may not have done so originally, there was also some evidence that the Civic Platform-Law and Justice divide increasingly reflected and mapped onto deeper ideological and socio-cultural divisions ${ }^{78}$ and that the two electorates' social bases were becoming somewhat more clearly defined: with Law and Justice voters older, more rural and religious, and less well educated and Civic Platform supporters younger, more urban, better off, better educated, and more secular. ${ }^{79}$ In fact, in many ways, the deep political polarisation and bitterness that characterised the two parties' on-going rivalry meant that they became the main points of reference for each other, with the existence of (and repellence from) the other being the key to their political appeal; and possibly even

\footnotetext{
${ }^{74}$ For interesting analyses of the similarities and differences between the two parties see: P. Zaremba, 'Wszytkie fronty wojny PO i PiS', 24 April 2009, www.dziennik.pl (Accessed 24 April 2009); A. Rychard, 'Podział Polski nie jest tak głęboki jak sugeruje to temperature sporu', 13 May 2010, www.polskatimes.pl (Accessed 16 May 2010); P. Gursztyn, 'Między colą a pepsi', Rzeczpospolita, 27 May 2010; R. Matja, 'Tak bliskie, tak dalekie', Polityka, 4 September 2010; and P. Gursztyn, 'Tacy sami', Rzeczpospolita, 28 October 2010.

${ }^{75}$ See, for example: M. Janicki, 'Presji agresji', Polityka, 30 October 2010.

${ }^{76}$ See: CBOS, Poparcie dla partii politycznych - pewność decyzji wyborczych, alternatywy wyborcze $i$ preferencje niezdecydowanych, August 2005 (July 2005 data), CBOS: Warsaw, p7; and Wybory parlamentarne $2011, \mathrm{p} 8$.

${ }^{77}$ See: Wybory parlamentarne 2011, p12.

${ }^{78}$ See, for example: I. Krzemiński, 'Drastyczne rozerwana wspólnota', Rzeczposolita, 12 April 2011.

${ }^{79}$ See: 'The 2007 Polish Parliamentary Election', p1064. Jasiewicz identified the two parties' supporters at opposite ends of a 'solidarism-liberalism' continuum which pitted 'market friendly and inclusive liberals...against the redistributionist populists'. See: K. Jasiewicz, "'The Past is Never Dead": Identity, Class and Voting Behaviour in Contemporary Poland', East European Politics and Societies, Vol 23 No 4, pp491-508 (506).
} 
very existence. ${ }^{80}$ Thus, it was in the political interests of both parties to keep their respective electorates deeply mistrustful of each other, leaving them in a kind of mutual political 'death grip' where if one of the two rivals were to disappear from the political scene this would create a (potentially existential) crisis for the other.

Moreover, all the various attempts during this period to develop an alternative to the Civic Platform-Law and Justice duopoly on the right and centre-right ended in failure. In this election, this included the attempt by 'Poland is the Most Important' to position itself at the interstice of the two large electoral blocs: more socially and culturally conservative than Civic Platform but more moderate than Law and Justice and more economically liberal than both of them. At one point, this appeared to be a promising location on the political spectrum for a new formation to emerge, given the large number of Law and Justice liberals and moderates who became alienated from their party over the years and Civic Platform conservatives potentially disillusioned at the party's recent 'shift to the left'. Indeed, early polls in the 2011 election campaign suggested that 'Poland is Most Important' had a better chance of making a breakthrough than the Palikot Movement. However, apart from the heavy blow of Mrs Kluzik-Rostkowska's defection to Civic Platform, the new party could not find a way of engaging with voters and carving out a political niche for itself. ${ }^{81}$ The fate of 'Poland is the Most Important' thus highlighted the apparent resilience of the Civic Platform-Law and Justice divide.

At the same time, as Table 4 shows, Civic Platform and Law and Justice once again easily confirmed their positions as the largest parties securing a combined share of the vote and seats of $69.07 \%$ and $79.13 \%$ respectively; albeit down from $73.62 \%$ and $85.92 \%$ in 2007 . Moreover, the election also saw a substantial fall in the level of aggregate electoral volatility calculated according to the so-called 'Pederson index' from 24.6\% in 2007 (and a massive $49.3 \%$ in 2001 ) to only $13.5 \%{ }^{82}$ although it remained high by European standards. ${ }^{83}$

\footnotetext{
${ }^{80}$ For more on the symbiotic relationship between the two parties, see, for example: C. Michalski, 'Oni żywią się nienawiścią, Newsweek, 31 October 2010.

${ }^{81}$ See, for example: Ł. Warzecha, 'PJN, czyli polityczna efemeryda', Rzeczpospolita, 14 March 2011; and P. Semka, 'Ciekawa oferta dla nikogo', Rzeczpospolita, 10 October 2011.

${ }^{82}$ See: 'The 2007 Polish Parliamentary Election', p1059. The 2011 figure is based on the author's calculations.

${ }^{83}$ The average level of aggregative volatility in West European elections between 1960-89 was 8.4\%. See: P. Mair, Party System Change: Approaches and Interpretations, Oxford: Clarendon Press, 1997, p182.
} 
Table 4: Party fragmentation in post-1989 Poland

\begin{tabular}{|l|c|c|c|c|c|c|c|}
\hline & 1991 & 1993 & 1997 & 2001 & 2005 & 2007 & 2011 \\
\hline $\begin{array}{l}\text { Number of parties elected } \\
\text { to the Sejm }\end{array}$ & 29 & 6 & 5 & 6 & 6 & 4 & 5 \\
\hline $\begin{array}{l}\text { Share of votes won by two } \\
\text { largest parties (\%) }\end{array}$ & 24.31 & 35.81 & 60.96 & 53.72 & 51.13 & 73.62 & 69.07 \\
\hline $\begin{array}{l}\text { Share of seats won by two } \\
\text { largest parties (\%) }\end{array}$ & 25.52 & 65.87 & 79.35 & 61.09 & 62.6 & 81.52 & 79.13 \\
\hline
\end{tabular}

Source: R. Markowski and M. Cześnik, 'Polski system partyjny: dekada zmian instytucjonalnych i ich konsekwencje,' in R. Markowski (ed.), System Partyjny $i$ Zachowanie Wyborcze: Dekada Polskich Doświadczeń, Warsaw: ISP PAN, 2002, pp.17-47(20); and author's calculations.

Another factor that appeared to encourage party system consolidation and stabilisation was the Polish state party funding regime established in 2001. Since then, the state became the largest source of income for the main Polish parties at a time when political campaigning was increasingly professionalised, and therefore costly. Although it was scaled back somewhat at the beginning of 2011, this development clearly favoured the larger 'insider' parties like Civic Platform and Law and Justice and made it increasingly difficult for new entrants to challenge this duopoly. ${ }^{84}$

However, other evidence suggested that the Polish political scene was more fluid and potentially unstable than appeared on the surface ${ }^{85}$ and that, in the longer-term, there was a possibility of further party re-alignment. Firstly, as Table 2 shows and this election once again confirmed, electoral turnout in Polish parliamentary elections remained extremely low, suggesting that, notwithstanding the apparent fall in the level of electoral volatility, the Polish electorate remained relatively 'open' and available to potential challenger parties.

Secondly, although the Civic Platform-Law and Justice divide appeared to reflect deeper ideological and cultural divisions within Polish society, levels of party institutionalisation remained low and the nature of the links between parties and their supporters extremely

\footnotetext{
${ }^{84}$ See, for example: J. Zbieranek, "The system of financing political parties in Poland - experience and challenges', in J. Kucharczyk and J. Zbieranek, eds. Democracy in Poland 1989-2009: Challenges for the Future, 2010, ISP: Warsaw, pp77-87.

${ }^{85}$ See: F. Millard, 'Poland: Parties without a Party System, 1991-2008', Politics and Policy, Vol 37 No 4 , August 2009, pp781-798.
} 
weak. For example, according to a survey of 27 countries from the mid-to-late 2000s Poland had one of the lowest levels of party membership in Europe, at only $0.99 \%$ as a percentage of the electorate $(304,465$ members) compared with the average of $4.65 \%$; and this figure had actually fallen from $1.15 \%$ at the end of the $1990 \mathrm{~s} .{ }^{86}$ This stemmed partly from the fact that Polish parties had made few attempts to develop organic links with and 'encapsulate' their supporters. But it was also because Poles had extremely negative attitudes towards parties so that even if party strategists actively sought to recruit substantially more members their prospects for success would have been slim. For example, a September-October 2011 CBOS survey found that most respondents felt that political parties: caused arguments and confusion (90\%), comprised cliques of power-seeking politicians (86\%), were driven primarily by personal ambition (77\%), did more harm than good (83\%) and did not really know what they wanted $(69 \%) .{ }^{87}$ Similarly, a September 2011 TNS OBOP survey found that the main reason cited by non-voters (37\% of respondents) for not participating in Polish elections was that they did not trust Polish parties and politicians. ${ }^{88}$ Survey evidence also suggested that levels of party identification had actually fallen in recent years. For example, a June 2008 CBOS survey found that the number of respondents who felt that there were no parties with whom they identified at all had increased from $27 \%$ in 1998 to $50 \%$ in 2008 . Only $36 \%$ clearly identified with a political party in 2008 compared with $57 \%$ in $1998 .{ }^{89}$ This, together with continuing low electoral turnout, suggested that neither of the two big electoral blocs had really succeeded in rooting themselves solidly in the Polish electorate.

Thirdly, while the Polish state party funding regime certainly discriminated in favour of the existing parties, this did not mean that there was no scope at all for new entrants. Indeed, the breakthrough of the Palikot Movement showed how a challenger party could emerge regardless of the state party funding barrier. The new party only spent only 1.7 million złoties

\footnotetext{
${ }^{86}$ See: I. van Biezen, P. Mair and T. Poguntke, 'Going, going...gone? The decline of party membership in contemporary Europe', European Journal of Political Research, Vol 51 No 1, January 2012, pp24-56 (28, 45).

${ }^{87}$ Admittedly, $41 \%$ of respondents also felt that if there were no political parties this would be harmful for the country (compared with $23 \%$ who said it would be advantageous) although this was down from $53 \%$ in 2001 . See: CBOS, Opinie o działalności partii politycznych, November 2011 (September-October 2011 data), pp2, 4 and 6.

${ }^{88}$ See: J. Stróżyk, 'Nie glosują, bo nie ufają politykom', Rzeczpospolita, 22 September 2011.

${ }^{89}$ See: CBOS, Partie bliższe $i$ dalsze - identyfikacje partyjne Polaków, July 2008 (June 2008), CBOS: Warsaw, p1.
} 
on its 2011 campaign compared to 30 million by Law and Justice, 29 million by Civic Platform, 24 million by the Democratic Left Alliance and 13 million by the Peasant Party. ${ }^{90}$

Fourthly, and more profoundly, arguably the 'ideological glue' holding Civic Platform and Law and Justice together was much weaker than might have appeared on the surface. These parties' long-term future cohesion depended upon their ability to frame the kind of broad, integrative ideological narratives which play a crucial role in holding broad parties together, and provide a sustainable basis for the development of, durable, diverse and heterogeneous political formations. They frame political action, give such parties purposiveness and identity as political organisations, and socialise incoming leadership elites thereby helping diverse political formations in post-communist states to hold together, particularly when they encounter periods of political crisis. ${ }^{91}$ Although both Civic Platform and Law and Justice had at various points in their short histories attempted to develop more complex ideological narratives centring on the nature of post-communist transformation it was questionable whether they had succeeded in doing so.

Arguably, and surprisingly given that the party just achieved a historic second consecutive election victory, it was Civic Platform that always had the relatively weaker ideological underpinnings. Initially, the party had attempted to profile itself as a modernising form of pro-market, right-wing liberalism focusing on economic issues (its early flagship policy was introducing a 15\% 'flat tax') and subsequently incorporated a national-patriotic appeal and moderate form of social conservatism (even elements of Euroscepticism). However, particularly since the 2007 election, Civic Platform appeared self-consciously to have functioned more as a 'catch-all' party downplaying both its economic liberalism and social conservatism. Instead, it presented itself as a somewhat amorphous modernising and proEuropean moderate grouping in opposition to the forces of provincial conservative nationalism, exemplified (allegedly) by Law and Justice. ${ }^{92}$ Specifically, this involved aligning the party more closely with the liberal-left cultural and media establishment; with

\footnotetext{
90 See: PKW, Komunikat Państwowej Komisji Wyborczej z dnia 13 lutego 2012 r.w sprawie sprawozdań finansowych komitetów wyborczych uczestniczacych $w$ wyborach do Sejmu Rzeczypospolitej Polskiej i do Senatu Rzeczypospolitej Polskiej, przeprowadzonych w dniu 9 października 2011 r, 13 February 2012, http://pkw.gov.pl/wybory-do-sejmu-rp-i-do-senatu-rp-2011/komunikat-panstwowej-komisji-wyborczej-z-dnia13-lutego-2012-r.html (Accessed 16 February 2012).

${ }^{91}$ See: S. Hanley, A. Szczerbiak, T. Haughton and B. Fowler, 'Sticking Together: Explaining Comparative Centre-right Party Success in Post-Communist Central and Eastern Europe', Party Politics, Vol 14 No 4, July 2008, pp407-434.

92 See, for example: Ł. Warzecha, 'Donald Tusk, czyli magma doskonała', Rzeczpospolita, 7 October 2011.
} 
whom Civic Platform had, on occasions, had a rather uneasy relationship. ${ }^{93}$ In other words, as discussed above, in the 2007-11 parliament the party adopted a deliberate strategy of diluting its profile in pursuit of electoral success and dominance and increasingly became a nonideological ('post-political' to use the Polish term) 'party of power'. However, while Civic Platform's ability to garner the support of broad swathes of the electorate in opposition to a polarising challenger clearly provided it with an extremely effective short-term electionwinning strategy, this success was conjunctural. It also moved the party away from developing the kind of integrative ideological underpinning that would have provided it with a firmer basis for more enduring, long-term organisational stability. In other words, Civic Platform began to lose its sense of common purpose and mission as it developed into an (arguably) unfeasibly broad political construct making it more vulnerable to implosion if it faced a serious internal crisis.

At one point Law and Justice's 'Fourth Republic' project of wide ranging moral and political renewal did potentially appear to provide the party with just such an integrative ideological narrative. For sure, as noted above, the 'Fourth Republic' project developed extremely negative connotations and came to be used increasingly as a tool for mobilising those Polish voters who found Mr Kaczyński's party too confrontational. Nonetheless, however distorted and cynical its critics might have argued that it was, it did represent a fairly serious attempt to develop a powerful and coherent conservative-national project. However, the party proceeded to abandon the 'Fourth Republic' narrative - for example, by downplaying issues such as crime, corruption and the need for moral and political renewal in the 2011 election campaign $^{94}$ - which may have been justified on short-term electoral-strategic grounds, but risked damaging its longer-term cohesion and purposiveness.

At one point, it appeared that Law and Justice was trying to use the emotions surrounding the Smolensk tragedy, and concomitant portrayal of the late President Kaczyński as a national martyr, as a new 'mobilising myth' that could provide bind its supporters closer to the party. ${ }^{95}$ This may have been effective as a means of mobilising the party's core electorate, and potentially even enough to secure election victory on the basis of low turnout. However,

\footnotetext{
${ }^{93}$ See: P. Gursztyn, 'Platforma z zwarciu z Kościołem', Rzeczpospolita, 22 October 2010; and P. Gursztyn, 'PO i antiklerykalizm', Rzeczpospolita, 14 July 2011.

94 See: 'O czym nie mówią politycy'.

${ }^{95}$ See: R. Krasowski, 'Kod smoleński', Polityka, 22 January 2011; and P. Gursztyn, 'Prawo i Sprawiedliwość. I Smoleńsk', Rzeczpospolita, 12 April 2011.
} 
ultimately it was not enough to either provide the basis for short-term electoral success nor, given that its effectiveness was sure to fade with time, act as a substitute integrative narrative capable of helping the party secure its longer-term survival. The danger for Law and Justice as it faced the difficult challenges of party renewal and coping with successive electoral defeats, which often trigger centrifugal forces within parties, was that it would transmogrify into a vehicle for its guru-like leader. For sure, Mr Kaczyński was a charismatic figure who generated an extremely loyal following on the Polish right, it was difficult to envisage the party's survival without him at its head, and even appeared impossible to build a successful right-wing formation in Poland that was not based on his leadership. However, except for the brief, exceptional period immediately after the Smolensk tragedy, he was also one of the country's least trusted and most un-popular politicians. The 2011 election appeared to confirm that Mr Kaczyński was a politician who had reached the limits of his electoral and political potential and thereby made his party un-electable. ${ }^{96}$

The electoral success of the Palikot Movement, the other major development in this election, together with the dismal showing of Poland's establishment left party, the Democratic Left Alliance, brings us to the second set of issues regarding the long-term trajectory of Polish politics, namely: what kind of left would emerge in Poland and what role would these two groupings play would play in shaping its future? One the face of it, the Palikot Movement appeared to have identified and mobilised a new electorate among younger voters for whom the established parties were too timid and conservative on social issues. In fact, religion played a powerful role in shaping political views and structuring the political scene in post1989 Poland $^{97}$ and there was always a radical anti-clerical electorate. Indeed, in many ways, it was attitudes towards moral-cultural issues and the role of the Catholic Church in public life that defined the core electorates of the secular left and religious right. The latter had been a key element of right-wing electoral blocs such as Law and Justice, and earlier the Solidarity Electoral Action (Akcja Wyborcza Solidarność: AWS) conglomerate, and provided the main base of support for clerical-nationalist parties such as the Christian National Union (Zjednoczenie Chrześcijańsko-Narodowe: ZChN) in the 1990s and the League of Polish

\footnotetext{
96 See: M. Migalski, 'List otwarty do prezesa Jarosława Kaczyńskiego', 22 August 2010, http://migalski.blog.onet.pl/List-otwarty-do-prezesa-Jarosl,2,ID413141639,n (Accessed 25 August 2010).

${ }^{97}$ See, for example: See: K. Jasiewicz,'Portfel czy róźanieć? Wzory zachowań wyborczych polaków w latach 1995-2001' in R. Markowski (ed.), System Partyjny i Zachowanie Wyborcze: Dekada Polskich Doświadczeń (Warsaw: ISP PAN, 2002), pp.75-100: and M. Grabowska, 'Religijność i kościół a polityka w III Rzeczpospolitej' in R. Markowski (ed.), System Partyjny $i$ Zachowanie Wyborcze: Dekada Polskich Doświadczeń (Warsaw: ISP PAN, 2002), pp.100-146.
} 
Families (Liga Polskich Rodzin: LPR) in the 2000s. The anti-clerical electorate, on the other hand, was garnered by the Democratic Left Alliance, for whom a commitment to a secular state was, in rhetorical terms at least, one of the party's signature issues. Indeed, as noted above, Mr Napieralski had actually focused quite heavily on this issue during the first phase of his leadership when he tried to portray himself as the 'Polish Zapatero'.

However, in practice the Democratic Left Alliance leadership was often prepared to compromise with the Catholic Church hierarchy, particularly when in government, and adopted a fairly pragmatic approach towards moral-cultural issues more generally. This was partly in order to achieve other objectives, such as ensuring that the Church maintained at least a neutral stance during the Polish EU accession process, and because radical anticlericalism on its own was not an election winning formula and felt to be a politically risky stance for a party that was trying to project a moderate self-image. ${ }^{98}$ But it was also because the Democratic Left Alliance leadership did not want to alienate less well-off economically leftist voters who were either not interested in social liberalism or actually quite culturally conservative; and there were many of these even among those who were not particularly religious and felt that the Catholic Church played too prominent a role in public life. ${ }^{99}$

Mr Palikot - who, until the final stages of the campaign, looked like his project to build a political formation based primarily on an appeal to anti-clericalism was heading for failure ${ }^{100}$ - was, in one sense, therefore simply able to garner and mobilise this existing electorate with a carefully targeted and intelligently executed campaign which focused on exploiting the weakness and disillusion on this issue among a segment of Democratic Left Alliance and Civic Platform voters. Part of Mr Palikot's appeal was thus his ability to articulate some of the Democratic Left Alliance's traditional themes but with much greater determination and energy (indeed, arguably aggression) than Mr Napieralski's party. However, what was really different about the Palikot Movement's appeal was the way that it combined this anti-clerical message with hostility to the political establishment, very explicit social liberalism expressed in support for sexual minorities and toleration of 'soft' drugs, together with business-friendly

\footnotetext{
${ }^{98}$ See, for example: Andrzej Rychard, 'Polacy nie lubią skrajności', Rzeczpospolita, 10 April 2008; and T. Nałęcz, 'Garnitur Zapatero, buty I sekretarza PZPR', Newseek, 15 June 2008.

${ }^{99}$ See: M. Szułdrzyński, 'Nowa lewica za mgła obietnic', Rzeczpospolita, 11 April 2008. Indeed, research on Democratic Left Alliance party activists also found them to hold socially and culturally conservative views. See: J. Harłukowicz, 'Sojusz od Lewicy Daleko', 18 November 2008, www.wyborcza.pl (Accessed 21 November 2008).

${ }^{100}$ See, for example: P. Gursztyn, 'PO i SLD już nie boją się Palikota', Rzeczpospolita, 2 November 2010.
} 
economic liberalism and support for a 'leaner' state. ${ }^{101}$ All of this was pulled together into an over-arching electoral appeal based on a kind of 'libertarian modernisation' and communicated using a language and campaigning style particularly attractive to younger voters. On its own, this was not an election winning formula but it was a genuinely new phenomenon in Polish politics and a potentially significant enough constituency to provide the basis for a moderately successful political party. ${ }^{102}$

However, given Mr Palikot's poor record as a parliamentarian ${ }^{103}$ and the fact most of the new deputies that he brought into parliament had no political experience, ${ }^{104}$ the longer term electoral (and even organisational survival) prospects for his Movement were not necessarily all optimistic ones. Some of his new MPs were controversial figures and potentially quite offputting to more moderate voters if they received greater exposure ${ }^{105}$ while, other less ideologically committed ones, particularly among the generally pragmatic local entrepreneurs who were elected on the party's electoral lists, could be tempted to defect to Civic Platform as the perceived 'party of power'. Moreover, it was difficult to see a party with such a strongly pro-business outlook and committed to small-government flat-tax economic liberalism re-inventing itself convincingly enough to broaden its appeal to less well-off voters. ${ }^{106}$ At the same time, although the Democratic Left Alliance's dismal showing clearly raised serious questions about whether it could remain a force in Polish politics it was too early to write off a party that retained a residual (although some would argue vestigial) 'core' of supporters including, as Table 3 shows, 58,500 paid up members ${ }^{107}$ and around 1,000 local councillors. ${ }^{108}$ This, together with the Palikot Movement's potential structural weaknesses and the limitations of its appeal, meant that, although the Alliance entered a period of crisis (possibly even an existential one), it was not inconceivable that it, or a party formed on its basis, would re-emerge as the major force on the Polish left.

\footnotetext{
${ }^{101}$ See: M. Janicki and W. Władyka, 'Palikotyzm', Polityka, 5-11 October 2011.

102 See: A. Stankiewicz and Z. Wojtkowska, 'Zastępy Palikota', Newsweek, 5 September 2010; and B. Wildstein, 'Gwiazda jednego sezonu', Rzeczpospolita, 11 October 2011.

${ }^{103}$ See: M. Magierowski, 'Polityk wagi ledwie koguciej’, Rzeczpospolita, 14 October 2011.

${ }^{104}$ See: I. Kacprzak et al, 'Janusz Palikot i jego drużyna', Rzeczpospolita, 12 October 2011; C. Łazarewicz, 'Lud Palikota', Polityka, 12-18 October 2011; and I. Ryciak and Z. Wojtkowska, 'Palikotki', Newsweek, 17-23 October 2012.

${ }^{105}$ See, for example: W. Czuchnowski, “'Fakty i Mity” Ruchu Palikota', 12 October 2011, www.wyborcza.pl (Accessed 12 October 2011)

${ }^{106}$ See: L. Jażdźewski, ‘Czas decyzji’, 1 November 2011, www.wyborcza.pl (Accessed 2 November 2011).

${ }^{107}$ As Table 3 shows, the Palikot Movement also claimed around 40,000 members but it was estimated that only around 2,000 of these actually membership subscriptions. See: A. Kublik, 'SLD się liczy', 5 November 2011, www.wyborcza.pl (Accessed 10 November 2011).

${ }^{108}$ See: 'Platforma wygrała, ale to PSL świętuje'.
} 


\section{$\underline{\text { Conclusion }}$}

The key to the Civic Platform's victory in the 2011 election was, therefore, its ability to generate fear about the possible consequences of Law and Justice returning to power. Although many of the party's supporters were disappointed with its slow progress in modernising the country, most voters clearly viewed Civic Platform as the better guarantor of stability at a time of crisis and continued to harbour deeply ingrained concerns about the main opposition party. Memories of Mr Kaczyński's previous period in office were evidently still fresh enough to mobilise these disillusioned Civic Platform voters. In the event, enough Civic Platform supporters came out to vote to give Mr Tusk's party its historically unprecedented second victory by a very clear margin. If the 2007 election was a referendum on the outgoing Law and Justice government then the 2011 poll turned into one on whether the main opposition party offered a credible alternative to Mr Tusk's administration, and most voters felt that it did not.

The election also appeared to provide further evidence of the consolidation and stabilisation of the Polish party system around the Civic Platform-Law and Justice divide. These two groupings confirmed their positions as the largest parties and attempts to develop an alternative to their duopoly on the centre-right once again ended in failure. However, other factors pointed to the dangers of declaring that the Polish party system was 'frozen' around these large political blocs and suggested that it remained vulnerable to further shocks and realignments. The 'ideological glue' holding the two big parties together was much weaker than appeared on the surface. Polish election turnout remained extremely low by European standards and this, together with the weak nature of the links between parties and their supporters, meant that the electorate remained 'open' and available to potential challenger parties. Indeed, the breakthrough of the Palikot Movement showed how such a challenge could emerge regardless of the fact that the state party funding regime discriminated in favour of the existing larger parties.

Mr Palikot's electoral success was due partly to his ability to simply mobilise an existing anti-clerical electorate through a carefully targeted and intelligently executed campaign. However, he combined this message with a broader appeal based on hostility to the political establishment, very explicit social liberalism, and support for a business-friendly 'leaner' 
state, and used a language and campaigning style that was particularly attractive to younger voters. This was not an election winning formula but it was a genuinely new phenomenon in Polish politics and potentially a significant enough constituency to provide a social base for a moderately successful political party. However, the Palikot Movement's potential structural weaknesses and the limitations of its appeal meant it was questionable whether this new party would be the long-term beneficiary of any revival on the Polish left. 


\section{Working Papers in Contemporary European Studies}

1. Vesna Bojicic and David Dyker

June 1993

Sanctions on Serbia: Sledgehammer or Scalpel

2. Gunther Burghardt

August 1993

The Future for a European Foreign and Security Policy

February 1994

3. Xiudian Dai, Alan Cawson, Peter Holmes

Competition, Collaboration \& Public Policy: A Case Study of the

European HDTV Strategy

4. Colin Crouch

February 1994

The Future of Unemployment in Western Europe? Reconciling Demands for Flexibility, Quality and Security

5. John Edmonds

February 1994

Industrial Relations - Will the European Community Change Everything?

6. Olli Rehn

July 1994

The European Community and the Challenge of a Wider Europe

7. Ulrich Sedelmeier October 1994

The EU's Association Policy towards Central Eastern Europe: Political and Economic Rationales in Conflict

8. Mary Kaldor

February 1995

Rethinking British Defence Policy and Its Economic Implications

9. Alasdair Young

December 1994

Ideas, Interests and Institutions: The Politics of Liberalisation in the EC's Road Haulage Industry

10. Keith Richardson

December 1994

Competitiveness in Europe: Cooperation or Conflict?

11. Mike Hobday

June 1995

The Technological Competence of European Semiconductor Producers

12. Graham Avery

July 1995

The Commission's Perspective on the Enlargement Negotiations

13. Gerda Falkner

The Maastricht Protocol on Social Policy: Theory and Practice

14. Vesna Bojicic, Mary Kaldor, Ivan Vejvoda

November 1995 
15. Alasdair Smith, Peter Holmes, Ulrich Sedelmeier, March 1996

Edward Smith, Helen Wallace, Alasdair Young

The European Union and Central and Eastern Europe: Pre-Accession Strategies

16. Helen Wallace

March 1996

From an Island off the North-West Coast of Europe

17. Indira Konjhodzic

June 1996

Democratic Consolidation of the Political System in Finland, 1945-1970:

Potential Model for the New States of Central and Eastern Europe?

18. Antje Wiener and Vince Della Sala

December 1996

Constitution Making and Citizenship Practice - Bridging the Democracy

Gap in the EU?

19. Helen Wallace and Alasdair Young

Balancing Public and Private Interests Under Duress

December 1996

20. S. Ran Kim

April 1997

Evolution of Governance \& the Growth Dynamics of the Korean

Semiconductor Industry

21. Tibor Navracsics

June 1997

A Missing Debate?: Hungary and the European Union

22. Peter Holmes with Jeremy Kempton

September 1997

Study on the Economic and Industrial Aspects of Anti-Dumping Policy

23. Helen Wallace

January 1998

Coming to Terms with a Larger Europe: Options for Economic

Integration

24. Mike Hobday, Alan Cawson and S Ran Kim

January 1998

The Pacific Asian Electronics Industries: Technology Governance

and Implications for Europe

25. Iain Begg

August 1998

Structural Fund Reform in the Light of Enlargement

Centre on European Political Economy Working Paper No. 1

26. Mick Dunford and Adrian Smith

August 1998

Trajectories of Change in Europe's Regions: Cohesion,

Divergence and Regional Performance

Centre on European Political Economy Working Paper No. 2

27. Ray Hudson

August 1998

What Makes Economically Successful Regions in Europe Successful? 
Implications for Transferring Success from West to East

Centre on European Political Economy Working Paper No. 3

28. Adam Swain

August 1998

Institutions and Regional Development: Evidence from Hungary and

Ukraine

Centre on European Political Economy Working Paper No. 4

29. Alasdair Young

October 1998

Interpretation and 'Soft Integration' in the Adaptation of the European

Community's Foreign Economic Policy

Centre on European Political Economy Working Paper No. 5

30. Rilka Dragneva

March 1999

Corporate Governence Through Privatisation: Does Design Matter?

31. Christopher Preston and Arkadiusz Michonski

March 1999

Negotiating Regulatory Alignment in Central Europe: The Case of the

Poland EU European Conformity Assessment Agreement

32. Jeremy Kempton, Peter Holmes, Cliff Stevenson

September 1999

Globalisation of Anti-Dumping and the EU

Centre on European Political Economy Working Paper No. 6

33. Alan Mayhew

March 2000

Financial and Budgetary Implications of the Accession of Central and East European Countries to the European Union.

34. Aleks Szczerbiak

May 2000

Public Opinion and Eastward Enlargement - Explaining Declining

Support for EU Membership in Poland

35. Keith Richardson

September 2000

Big Business and the European Agenda

36. Aleks Szczerbiak and Paul Taggart

October 2000

Opposing Europe: Party Systems and Opposition to the Union, the Euro and Europeanisation

Opposing Europe Research Network Working Paper No. 1

37. Alasdair Young, Peter Holmes and Jim Rollo

November 2000

The European Trade Agenda After Seattle

38. Sławomir Tokarski and Alan Mayhew

December 2000

Impact Assessment and European Integration Policy

39. Alan Mayhew

December 2000

Enlargement of the European Union: an Analysis of the Negotiations with the Central and Eastern European Candidate Countries 
40. Pierre Jacquet and Jean Pisani-Ferry

January 2001

Economic Policy Co-ordination in the Eurozone: What has been achieved? What should be done?

41. Joseph F. Francois and Machiel Rombout February 2001

Trade Effects From The Integration Of The Central And East European Countries Into The European Union

42. Peter Holmes and Alasdair Young February 2001

Emerging Regulatory Challenges to the EU's External Economic Relations

43. Michael Johnson

March 2001

EU Enlargement and Commercial Policy: Enlargement and the Making of Commercial Policy

44. Witold Orłowski and Alan Mayhew May 2001

The Impact of EU Accession on Enterprise, Adaptation and Institutional Development in the Countries of Central and Eastern Europe

45. Adam Lazowski

May 2001

Adaptation of the Polish legal system to European Union law: Selected aspects

46. Paul Taggart and Aleks Szczerbiak

May 2001

Parties, Positions and Europe: Euroscepticism in the EU Candidate

States of Central and Eastern Europe

Opposing Europe Research Network Working Paper No. 2

47. Paul Webb and Justin Fisher

May 2001

Professionalizing the Millbank Tendency: the Political Sociology of New

Labour's Employees

48. Aleks Szczerbiak

June 2001

Europe as a Re-aligning Issue in Polish Politics?: Evidence from

the October 2000 Presidential Election

Opposing Europe Research Network Working Paper No. 3

49. Agnes Batory

September 2001

Hungarian Party Identities and the Question of European Integration

Opposing Europe Research Network Working Paper No. 4

50. Karen Henderson

September 2001

Euroscepticism or Europhobia: Opposition attitudes to the EU in the

Slovak Republic

Opposing Europe Research Network Working Paper No. 5

51. Paul Taggart and Aleks Szczerbiak

April 2002

The Party Politics of Euroscepticism in EU Member and Candidate States

Opposing Europe Research Network Working Paper No. 6.

52. Alan Mayhew

April 2002 
The Negotiating Position of the European Union on Agriculture, the Structural Funds and the EU Budget.

53. Aleks Szczerbiak

May 2002

After the Election, Nearing The Endgame: The Polish Euro-Debate in the Run Up To The 2003 EU Accession Referendum

Opposing Europe Research Network Working Paper No. 7.

54. Charlie Lees

June 2002

'Dark Matter': institutional constraints and the failure of party-based

Euroscepticism in Germany

Opposing Europe Research Network Working Paper No. 8

55. Pinar Tanlak

October 2002

Turkey EU Relations in the Post Helsinki phase and the EU

harmonisation laws adopted by the Turkish Grand National Assembly

in August 2002

56. Nick Sitter

October 2002

Opposing Europe: Euro-Scepticism, Opposition and Party Competition

Opposing Europe Research Network Working Paper No. 9

57. Hans G. Nilsson

November 2002

Decision Making in EU Justice and Home Affairs: Current Shortcomings and Reform Possibilities

58. Adriano Giovannelli

November 2002

Semipresidentialism: an emerging pan-European model

59. Daniel Naurin

December 2002

Taking Transparency Seriously

60. Lucia Quaglia

March 2003

Euroscepticism in Italy and centre Right and Right wing political parties

OpPosing Europe RESEARCH NeTWORK Working Paper No. 10

61. Francesca Vassallo

March 2003

Another Europeanisation Case: British Political Activism

62. Kieran Williams, Aleks Szczerbiak, Brigid Fowler

March 2003

Explaining Lustration in Eastern Europe: a Post-Communist Politics

Approach

63. Rasa Spokeviciute

March 2003

The Impact of EU Membership of The Lithuanian Budget

64. Clive Church

May 2003

The Contexts of Swiss Opposition to Europe

Opposing Europe Research Network Working Paper No. 11 
65. Alan Mayhew

May 2003

The Financial and Budgetary Impact of Enlargement and Accession

66. Przemysław Biskup June 2003

Conflicts Between Community and National Laws: An Analysis of the British Approach

67. Eleonora Crutini

Evolution of Local Systems in the Context of Enlargement

August 2003

68. Professor Jim Rollo

August 2003

Agriculture, the Structural Funds and the Budget After Enlargement

69. Aleks Szczerbiak and Paul Taggart

October 2003

Theorising Party-Based Euroscepticism: Problems of Definition,

Measurement and Causality

European Parties Elections and Referendums Network Working Paper No. 12

70. Nicolo Conti

November 2003

Party Attitudes to European Integration: A Longitudinal Analysis of the

Italian Case

European Parties Elections and Referendums Network Working Paper

No. 13

71. Paul Lewis

November 2003

The Impact of the Enlargement of the European Union on Central

European Party Systems

European Parties Elections and Referendums Network Working Paper

No. 14

72. Jonathan P. Aus

December 2003

Supranational Governance in an "Area of Freedom, Security and

Justice": Eurodac and the Politics of Biometric Control

73. Juraj Buzalk

February 2004

Is Rural Populism on the decline? Continuities and Changes in

Twentieth Century Europe: The case of Slovakia

74. Anna Slodka

Eco Labelling in the EU: Lessons for Poland

May 2004

75. Pasquale Tridico

May 2004

Institutional Change and Economic Performance in Transition

Economics: The case of Poland

76. Arkadiusz Domagala

August 2004

Humanitarian Intervention: The Utopia of Just War?

The NATO intervention in Kosovo and the restraints of Humanitarian Intervention

77. Marisol Garcia, Antonio Cardesa Salzmann \&Marc Pradel September 2004 
The European Employment Strategy: An Example of European

Multi-level Governance

78. Alan Mayhew

October 2004

The Financial Framework of the European Union, 2007-2013: New

Policies? New Money?

79. Wojciech Lewandowski

October 2004

The Influence of the War in Iraq on Transatlantic Relations

80. Susannah Verney

October 2004

The End of Socialist Hegemony: Europe and the Greek Parliamentary

Election of $7^{\text {th }}$ March 2004

EUROPEAN PARTIES ELECTIONS AND REFERENDUMS NETWORK Working Paper

No. 15

81. Kenneth Chan

November 2004

Central and Eastern Europe in the 2004 European Parliamentary

Elections: A Not So European Event

European Parties Elections and Referendums Network Working Paper

No. 16

82. Lionel Marquis

December 2004

The Priming of Referendum Votes on Swiss European Policy

European Parties Elections and Referendums Network Working Paper

No. 17

83. Lionel Marquis and Karin Gilland Lutz

December 2004

Thinking About and Voting on Swiss Foreign Policy: Does Affective

and Cognitive Involvement Play a Role?

European Parties Elections and Referendums Network Working Paper

No. 18

84. Nathaniel Copsey and Aleks Szczerbiak

March 2005

The Future of Polish-Ukrainian Relations: Evidence from the June 2004

European Parliament Election Campaign in Poland

85. Ece Ozlem Atikcan

May 2006

Citizenship or Denizenship: The Treatment of Third Country Nationals

in the European Union

86. Aleks Szczerbiak

May 2006

'Social Poland' Defeats 'Liberal Poland'?: The September-October 2005

Polish Parliamentary and Presidential Elections

87. Nathaniel Copsey

October 2006

Echoes of the Past in Contemporary Politics: the case of

Polish-Ukrainian Relations 
88. Lyukba Savkova

November 2006

Spoilt for Choice, Yet Hard to Get: Voters and Parties at the Bulgarian 2005 Parliamentary Election

89. Tim Bale and Paul Taggart

November 2006

First Timers Yes, Virgins No: The Roles and Backgrounds

of New Members of the European Parliament

90. Lucia Quaglia

November 2006

Setting the pace? Private financial interests and European financial market integration

91. Tim Bale and Aleks Szczerbiak

December 2006

Why is there no Christian Democracy in Poland

(and why does this matter)?

92. Edward Phelps

December 2006

Young Adults and Electoral Turnout in Britain: Towards a Generational

Model of Political Participation

93. Alan Mayhew

April 2007

A certain idea of Europe: Can European integration survive

eastern enlargement?

94. Seán Hanley, Aleks Szczerbiak, Tim Haughton

May 2007

and Brigid Fowler

Explaining the Success of Centre-Right Parties in Post-Communist

East Central Europe: A Comparative Analysis

95. Dan Hough and Michael Koß

Territory and Electoral Politics in Germany

May 2007

96. Lucia Quaglia

July 2007

Committee Governance in the Financial Sector in the European Union

97. Lucia Quaglia, Dan Hough and Alan Mayhew

You Can't Always Get What You Want, But Do You Sometimes Get

What You Need? The German Presidency of the EU in 2007

98. Aleks Szczerbiak

November 2007

Why do Poles love the EU and what do they love about it?: Polish

attitudes towards European integration during the first three years

of EU membership

99. Francis McGowan

January 2008

The Contrasting Fortunes of European Studies and EU Studies: Grounds

for Reconciliation?

100. Aleks Szczerbiak

January 2008

The birth of a bi-polar party system or a referendum on a polarising 
government: The October 2007 Polish parliamentary election

101. Catharina Sørensen

January 2008

Love me, love me not... A typology of public euroscepticism

European Parties Elections and Referendums NeTwork Working Paper No. 19

102. Lucia Quaglia

Completing the Single Market in Financial services: An Advocacy

Coalition Framework

103. Aleks Szczerbiak and Monika Bil

May 2008

When in doubt, (re-)turn to domestic politics?

The (non-) impact of the EU on party politics in Poland

European Parties Elections and Referendums Network Working Paper No. 20

104. John Palmer

Beyond EU Enlargement-Creating a United European Commonwealth

July 2008

105. Paul Blokker

September 2008

Constitutional Politics, Constitutional Texts and Democratic Variety in

Central and Eastern Europe

106. Edward Maxfield

September 2008

A New Right for a New Europe? Basescu, the Democrats \& Romania's centre-right

107. Emanuele Massetti

November 2008

The Scottish and Welsh Party Systems Ten Years after Devolution: Format, Ideological Polarization and Structure of Competition

108. Stefano Braghiroli

December 2008

Home Sweet Home: Assessing the Weight and Effectiveness

of National Parties' Interference on MEPs' everyday Activity

109. Christophe Hillion and Alan Mayhew

January 2009

The Eastern Partnership - something new or window-dressing

110. John FitzGibbon

September 2009

Ireland's No to Lisbon: Learning the Lessons from the

failure of the Yes and the Success of the No Side

European Parties Elections and REFERENDUMs Network Working Paper No. 21

111. Emelie Lilliefeldt September 2009

Political parties and Gender Balanced Parliamentary Presence in Western Europe: A two-step Fuzzy-set Qualitative Comparative Analysis

112. Valeria Tarditi

January 2010

THE SCOTTISH NATIONAL PARTY'S CHANGING ATTITUDE TOWARDS THE EUROPEAN UNION 
European Parties Elections and Referendums Network Working Paper No. 22

113. Stijn van Kessel

February 2010 Swaying the disgruntled floating voter. The rise of populist parties in contemporary Dutch politics.

114. Peter Holmes and Jim Rollo EU Internal Market: Shaping a new Commission Agenda 2009-2014.

April 2010

115. Alan Mayhew

June 2010

The Economic and Financial Crisis: impacts on an emerging economy - Ukraine

116. Daniel Keith

June 2010

The Portuguese Communist Party - Lessons in Resisting Change

117. Ariadna Ripoll Servent

June 2010

The European Parliament and the 'Returns' directive: The end of radical contestation; the start of consensual constraints?

118. Paul Webb, Tim Bale and Paul Taggart

October 2010 Deliberative Versus Parliamentary Democracy in the UK: An Experimental Study

119. Alan Mayhew, Kai Oppermann and Dan Hough April 2011 German foreign policy and leadership of the EU - 'You can't always get what you want ... but you sometimes get what you need'

120. Tim Houwen

June 2011

The non-European roots of the concept of populism

121. Cas Mudde

August 2011

Sussex v. North Carolina: The Comparative Study of Party Based Euroscepticism European Parties Elections and Referendums Network Working Paper No. 23

122. Marko Stojic

August 2011

The Changing Nature of Serbian Political Parties'Attitudes Towards Serbian EU Membership European Parties Elections and Referendums Network Working Paper No. 24

123. Daniel Keith September 2011

'When life gives you lemons make lemonade': Party organisation and the adaptation of West European Communist Parties

124. Marianne Sundlisæter Skinner October 2011

From Ambiguity to Euroscepticism? A Case Study of the Norwegian Progress Party's Position on the European Union European Parties Elections and Referendums Network Working Paper No. 25 
125. Amy Busby

October 2011

"You're not going to write about that are you?": what methodological issues arise when doing ethnography in an elite political setting?

126. Robin Kolodny

November 2011

The Bidirectional Benefits of Political Party Democracy Promotion: The Case of the UK's Westminster Foundation for Democracy

127. Tapio Raunio

February 2012

'Whenever the EU is involved, you get problems': Explaining the European policy of The (True) Finns

European Parties Elections and Referendums Network Working Paper No. 26

128. Alan Mayhew

March 2012

Reforming the EU budget to support economic growth

129. Aleks Szczerbiak

March 2012

Poland (Mainly) Chooses Stability and Continuity: The October 2011 Polish

Parliamentary Election

All Working Papers are downloadable free of charge from the web http://www.sussex.ac.uk/sei/publications/seiworkingpapers.

Otherwise, each Working Paper is $£ 5.00$ (unless noted otherwise) plus $£ 1.00$ postage and packing per copy in Europe and $£ 2.00$ per copy elsewhere. Payment by credit card or cheque (payable to 'University of Sussex'). 